Article

\title{
Land Use versus Land Cover: Geo-Analysis of National Roads and Synchronisation Algorithms
}

\author{
Katarzyna Kocur-Bera ${ }^{1, *(-)}$ and Agnieszka Dawidowicz ${ }^{2}(\mathbb{D})$ \\ 1 Institute of Geoinformation and Cartography, Faculty of Geodesy, Geospatial and Civil Engineering, \\ University of Warmia and Mazury in Olsztyn, 10-720 Olsztyn, Poland \\ 2 Institute of Geography and Land Management, Faculty of Geodesy, Geospatial and Civil Engineering, \\ University of Warmia and Mazury in Olsztyn, 10-720 Olsztyn, Poland; agnieszka.dawidowicz@uwm.edu.pl \\ * Correspondence: katarzyna.kocur@uwm.edu.pl
}

Received: 5 November 2019; Accepted: 13 December 2019; Published: 17 December 2019

\begin{abstract}
Technological progress in Earth surface observation provides a vast range of information on the land and methods of its use. This enables property owners, users and administrators to monitor the state of the boundaries of the land they own/administer. The land cover, monitored directly on the ground, is not always consistent with the land use entered in the Land and Property Registry (LPR). Discrepancies between these data are often found in former communist countries. One of the reasons for this was the rapid process of land privatisation, which took place in Poland, without updating information on the plot geodetic boundaries. The study examined and compared the land use (entered in the LPR) with the land cover (on the ground) for national roads (acr. LU-LC). The most frequent discrepancies were selected, using CLC2018, digital orthophotomaps (using the Web Map Service (WMS) browsing service compliant with Open Geospatial Consortium (OGC) standards), cadastral data, statistical modelling and an updated survey of the right-of-way. Subsequently, six algorithms were proposed to synchronise the land use and land cover when the right-of-way was used by unauthorised persons, and two algorithms for cases of unauthorised use of land by the road administrator. Currently, it is difficult to synchronise the land cover with the land use from the administrative, legal and social points of view. The results of analyses show that full synchronisation of land use and land cover is complicated and time-consuming, although desired.
\end{abstract}

Keywords: spatial analysis; updating data; land use/cover (acr. LU-LC); cadastral data; synchronisation algorithms

\section{Introduction}

Changes in the population's lifestyle and increases in their mobility and the consumption and transfer of goods on the local and global scale have significantly increased road transport. This particularly applies to the countries that joined the European Union during the past two decades, when the road infrastructure was backward compared to the other EU countries. Increased demand for transport [1] requires the right-of-way administration in a way which allows for fast and safe traffic [2]. It applies both to the part on which the motor traffic takes place (roadway) and the land which enables its proper functioning (right-of-way).

The experience of communism and the socioeconomic system transformation in Eastern European countries in the 1990s resulted in different treatment of common property and common resources [3]. They are regarded as "no-one's property". In some people's perception, it opens the possibility of using road infrastructure, public space or forests for one's private purposes. Such an approach has its consequences because - as this study shows-some public roads are used for non-transport purposes. This lack of coincidence of land use (the spatial range of public property administration) and land 
cover (acr. LU-LC) affects a number of aspects of life, from traffic safety, through road administration, to the portion of taxes received by communes.

The issues related to examination of changes of land use/land cover have been present in the scientific discourse, in particular with respect to changes in the environment [4,5], ecosystems [6-9], landscape $[10,11]$ and consequences to climate changes [12]. Causes for changes in the LU-LC are sought in a global approach; it is pointed out that they result from a population increase and intensive land use [13-15]. Such studies often take land use as equivalent to land cover, because land cover is a consequence of the way in which people use it $[16,17]$. Monitoring the LU-LC is of key importance in this aspect on the local, regional and global scale [18]. Unlike in the cited papers, the authors of this study distinguish between land use and land cover, assuming that land use represents entries in the Land and Property Registry (LPR), whereas land cover represents situations deviating from such entries in the LPR. Such an approach is of particular importance in the case of public roads. Owing to it, it was possible to determine the scale and type of LU-LC discrepancies on public roads and to identify solution algorithms which will help to synchronise LU and LC.

Discrepancies between data entered in the LPR and the state on the ground have been studied many times and are a multi-faceted issue. A group of researchers attempted to estimate the scale of obsolescence of cadastral data by comparing them to other sources employing modern technologies [19-22]. Another very important study trend focuses on using modern technologies to update or generalise data [23-26]. State-of-the-art tele-detection imaging in combination with deep learning method algorithms are used increasingly often [27-30]. A third group of articles presents an analysis of the effects of modernisation of cadastral data on an individual, a tax collecting authority, socioeconomic aspects and real estate management [31-36].

All of the issues discussed in studies associated with a lack of up-to-date cadastral data and methods of updating them are equally important. However, not each LU-LC discrepancy is a consequence of the fact that data are not updated; the mind-set of people, who treat public property in a specific manner, is also of great importance. This manuscript takes these issues into account and proposes an innovative approach based on legal solutions and good practice principles, which make it possible to achieve LU-LC synchronisation.

The aim of the study is to analyse the use of land that makes up a right-of-way. The authors analysed the CLC2018 data, digital orthophotomaps (using the Web Map Service browsing service compliant with the Open Geospatial Consortium standards) and the findings of the right-of-way geodetic survey performed on parts of national roads in the Warmińsko-Mazurskie Voivodship, Poland. Subsequently, the results were used to develop algorithms enabling synchronisation of land use and land cover. Eight algorithms were developed; six cover cases of land use by private entities, associations or other legal entities, whereas two algorithms concern synchronisation when road objects are situated on land not intended for the purpose.

This paper consists of six sections. Section 1 (introduction) presents the object and scope of the study, analyses the literature of the subject with respect to data updating and their consistency with the situation on the ground; Section 2 (background) presents the scope of responsibilities of a road administrator in the aspect of having complete and relevant information on the land that he administers. This section also points out geodetic procedures that enable altering the right-of-way cadastral data. Section 3 (methods and materials) presents the methods applied in the study and briefly characterises the area covered by the analyses, Section 4 (results) presents the results of the quantitative analyses in the area and proposes models whose application enables synchronisation of land use and land cover, Section 5 (discussion) analyses the quantitative results. The final section sums up the study results.

\section{Background}

A public road administrator has a number of responsibilities, from the stage of the road network planning, through its construction and maintenance, until the moment when it falls into disuse. A specific scope of responsibility is laid down in the relevant laws, rules and regulations. 
The responsibilities of a road administrator in Poland are associated mainly with: (1) Developing draft plans for road network development with plans for funding construction, alterations, repairs, maintenance and protection of roads and engineering structures; (2) maintenance of the road pavement, sidewalks, engineering structures, traffic protection devices and other road-related devices, except for the right-of-way part; (3) responsibilities related to traffic engineering; (4) preparing road infrastructure for national defence-related purposes; (5) coordination of work in the right-of-way; (6) issuing permits for occupying the right-of-way and for exits from roads as well as collecting fees and fines; (7) maintaining a register of roads, bridges, tunnels, culverts and ferries and providing it at a request of an authorised authority; (8) conducting periodical inspections of the condition of roads and road engineering structures; (9) performing intervention work, maintenance and securing work; (10) preventing road damage by users and adverse changes in the environment; (11) introducing traffic restrictions in situations when safety is threatened; (12) performing periodical traffic measurements; (13) maintaining roadside vegetation and (14) acquisition of land for right-of-way of public roads and managing it under the rights to the land [37]. These tasks would be difficult to perform without full information on the right-of-way, consistent with the situation on the ground.

There are two definitions that apply to roads and which describe differently the space used for traffic. These are: "road" and "right-of-way". The former definition applies to object(s) which are consistent with the common understanding of the space on which traffic takes place (road, bridge, etc.), whereas the latter defines a spatial dimension of management. According to the Public Road Act [37] "road" is a structure which includes such engineering structures as (e.g., overpasses, tunnels, passages under roads, retaining walls, etc.), devices and installations which make up a technical and utility whole, intended for traffic handling and located within a right-of-way [37,38]. "Right-of-way" denotes land delimited with boundary lines with the space above and below its surface, which contains the road, structures and engineering devices associated with traffic, its securing and handling, as well as devices used for purposes of the road administration [37]. There is a perceptible difference in the spatial range between these two definitions (Figure 1).

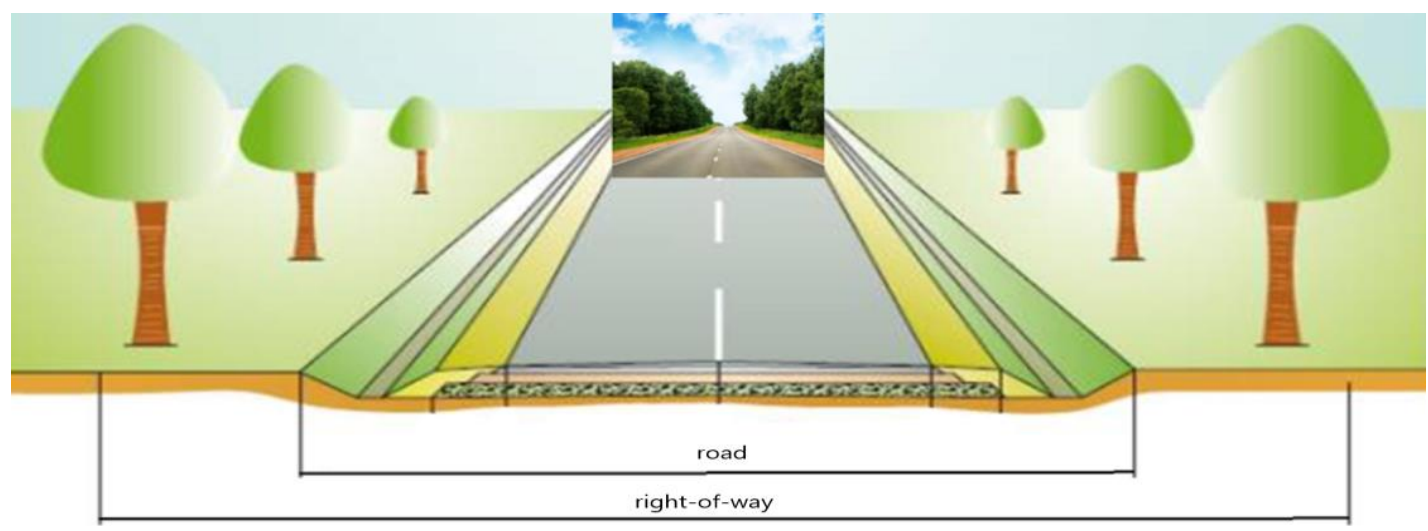

Figure 1. The spatial range of "road" and "right-of-way" according to the definition [37]. Source: Own study on [39].

Therefore, activities related to right-of-way administration covers a broader spatial dimension than the place used and commonly perceived for vehicles and people transfer. Studies conducted in this manuscript concern a right-of-way. This arises from the fact that in the Land and Property Registry, which is a part of land administration systems, enabling the fulfilling of the environmental, social and economic needs of the society [40,41], a right-of-way is described as a "road" and is intended for traffic in the spatial dimensions mentioned in the Public Road Act [37]. A right-of-way can consist of one, several, or even several hundred cadastral plots and it is subject to the same administrative and legal regulations as the other plots registered in the LPR. 
Discrepancies between the situation on the ground (land cover) and that described in documents (land use) are usually established during the process of updating LPR data or as part of a modernisation procedure [42]. The Land and Property Registry is a very important database from the economic and social perspective, and it should be up-to-date, whereas the data contained in it should be of good quality [43-45].

LPR data on a plot boundary can be obtained only from such sources that will ensure their proper accuracy (data from photogrammetric measurements, data from land consolidation and exchange, etc.) or from measurement activities performed with sufficient accuracy (property division, resuming boundary markers, etc.). In such cases, when these data exist, boundary points previously revealed in LPR are marked [42] (see Figure 2).

The situation is much more complicated when geodetic documentation does not contain data, which clearly confirm the position of boundary points on the ground or the data were read from archival graphic documents, and they are only marked on the ground (see Figure 3). In that case, missing data are established in the procedure of (a) resuming boundary marks as per art. 39 (1) [42]; (b) establishing the course of a plot boundary as per §37-39 [46]; (c) plot delimitation as per chapter 6 [43]; (d) establishing water body coastline as per art. 15 [47]; and (e) adopting property boundaries in the division procedure [48].

Updating data on public roads is subject to the same administrative and legal regulations as plots entered into the LPR. In the case of administering a right-of-way, it is important who actually administers it. This arises from the fact that the roads and tasks that road administrators are obliged to perform are divided into categories. In the opinion of some authors, information on a road's spatial range depends on the type of administrative task [49]. Public roads in Poland are divided into four categories, which take into account the administrative division of the country. These include: (1) Motorways, expressways, international roads, roads leading up to border crossing points, city ring roads, etc., are owned by the State Treasury; (2) roads connecting cities are owned by local governments of voivodships; (3) roads connecting county towns and commune villages and connecting commune villages with each other are owned by county local governments; (4) local roads which complement the road networks used for local purposes, are owned by commune local governments [34]. Discrepancies between the situation on the ground (land cover) and LPR data (land use) may make administering a right-of-way difficult and result in social and legal conflicts [31]. Conflicts are universal and timeless phenomena and they occur in all cultures and societies on various planes: political, economic, social, interpersonal, inter-group and international [50-52]. According to Kołodziejski [50], causes for spatial conflicts include: (1) Historically developed spatial structures; (2) having to meet social demands; (3) an ineffective legal and economic system, which forces a specific actions of business entities; (4) a deficit of funds for accomplishing specific goals; (5) high level of dispersion of the decision-making power within a specific managerial structure. Lack of LU-LC synchronisation is one of the causes of spatial conflicts. 


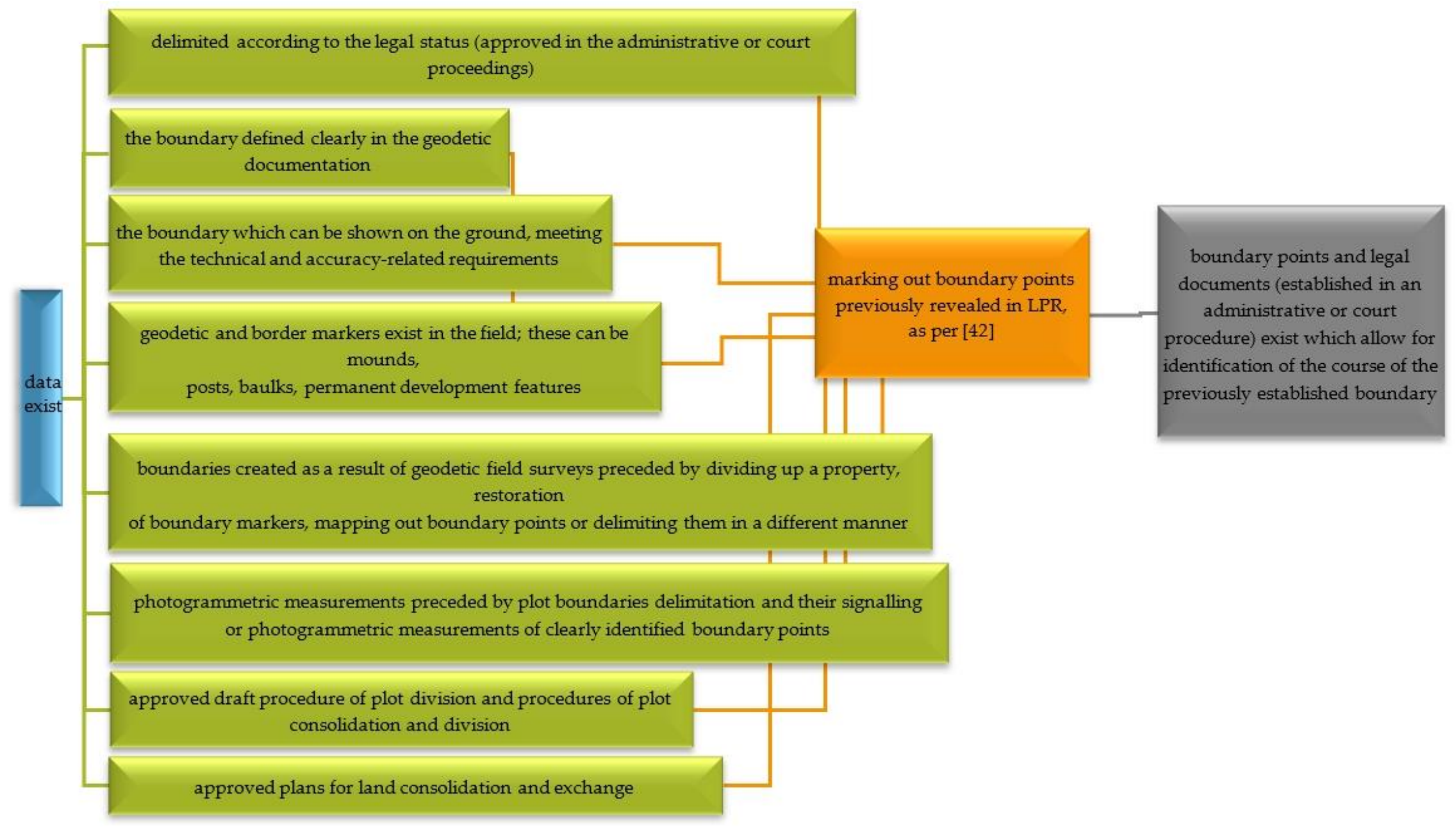

Figure 2. Administrative-legal procedures leading to the plot boundary delimitation when data exist. Source: Own study on [33,42,46-48]. 


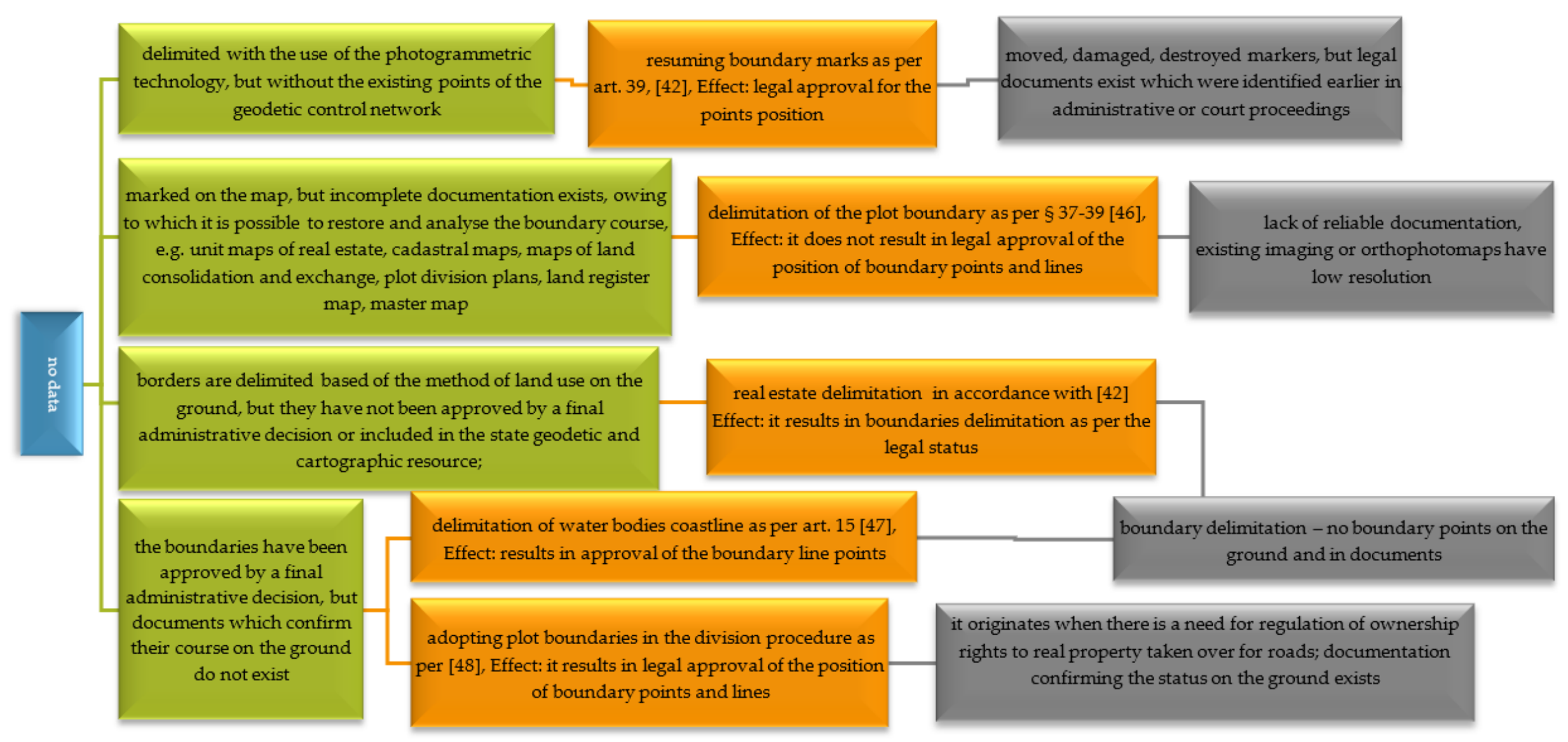

Figure 3. Administrative legal procedures leading to the plot boundary delimitation when the necessary data are missing. Source: Own study on [33,42,46-48]. 


\section{Materials and Methods}

\subsection{Description of Research Area}

The research area covers part of the national roads situated in the Warmia and Mazury region, Poland. They are administered by the General Directorate for National Roads and Motorways (acronym of the Polish name: GDDKiA), Olsztyn Branch. In total, GDDKiA in Poland administers roads of the total length of $19,295.80 \mathrm{~km}$ [53], which accounts for $4.6 \%$ of all public roads. A total of $4271.1 \mathrm{~km}$ of national roads run within town borders (i.e., more than $22.7 \%$ ), and the remaining $14,530 \mathrm{~km}$-outside town borders. The longest national road network is in the Mazowieckie Voivodship-2371.0 km, and the shortest is in Świętokrzyskie-754.6 km [54]. The European north-south road E77 and east-west road E28 run through the region under study. The road system in the region includes $1326.8 \mathrm{~km}$ of national roads, $1911.1 \mathrm{~km}$ of regional roads, $6979.8 \mathrm{~km}$ of county roads, and $2425.2 \mathrm{~km}$ of commune roads. The national roads in the region under study (see Figure 4) are international and inter-regional expressways (colour green in Figure 4), main roads of accelerated traffic (colour red in Figure 5) and main roads (colour blue in Figure 4). The study covered approx. 50\% of the national roads in the Warmińsko-Mazurskie Voivodship No. DK 15, DK 16, DK 22, DK 51, DK 53, DK 57, DK 58, DK 59, DK 63 and DK 65.

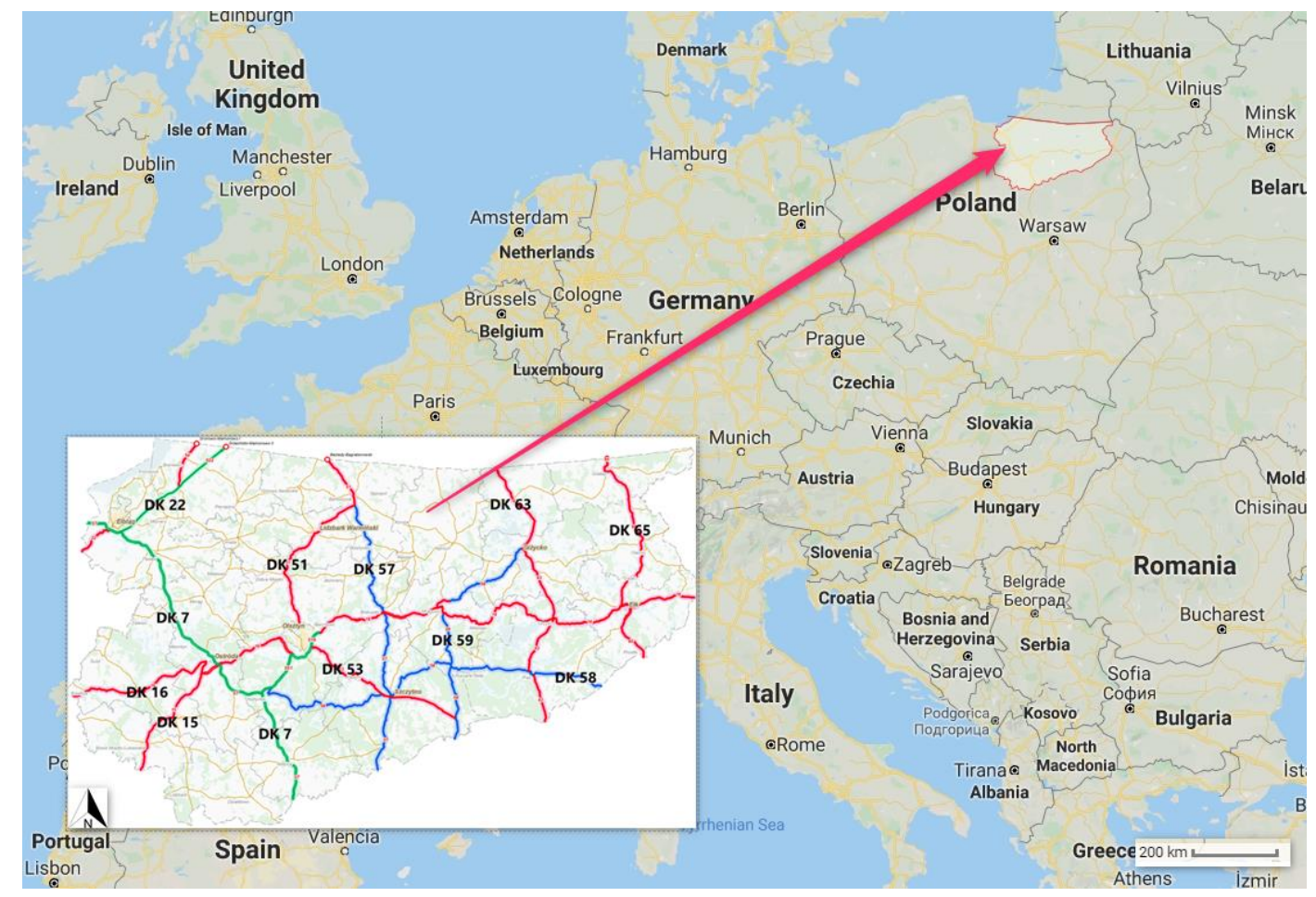

Figure 4. Study area. Source: Own study on $[55,56]$. DK-the abbreviation of national road (in polish: Droga Krajowa)

\subsection{Methodology}

The study was conducted in six stages. In order to identify the occurring LU-LC inconsistencies on national roads, Corine Land Cover 2018 (CLC2018) data, an orthophotomap, cadastral data and result of right-of-way geodetic update were used. Using QGis software, the areas where LU-LC inconsistencies on national roads are found were identified. Three incompatible land uses were found on national roads (1.1.1: continuous urban fabric, 2.3.1: pastures, 243: land principally occupied by agriculture, with significant areas of natural vegetation). LU-LC was then compared taking into account orthophotomaps and the results of the findings of the right-of-way geodetic survey. This update was carried out by various methods depending on the set of information on the boundaries of plots 
(see Figures 2 and 3). A method of statistical analysis and the hedonic model was used based on the discrepancies in area size (AREA LU-LC), their location (GEOloc.), land urbanisation (UA), where a discrepancy exists, and the present land use method for land intended for road traffic (LAND COVER) (stage 3-5). The form of the model was selected based on Akaike criterion [57,58]. The last study stage presents solution algorithms, which enable synchronisation of land use and land cover. The method of LU-LC synchronisation takes into account the valid laws and good practice principles. It should be noted that synchronisation can be achieved not only by a change in the land cover but also by signing a civil legal agreement, under which a user can use the right-of-way for other purposes. Figure 5 shows the stages of the study.

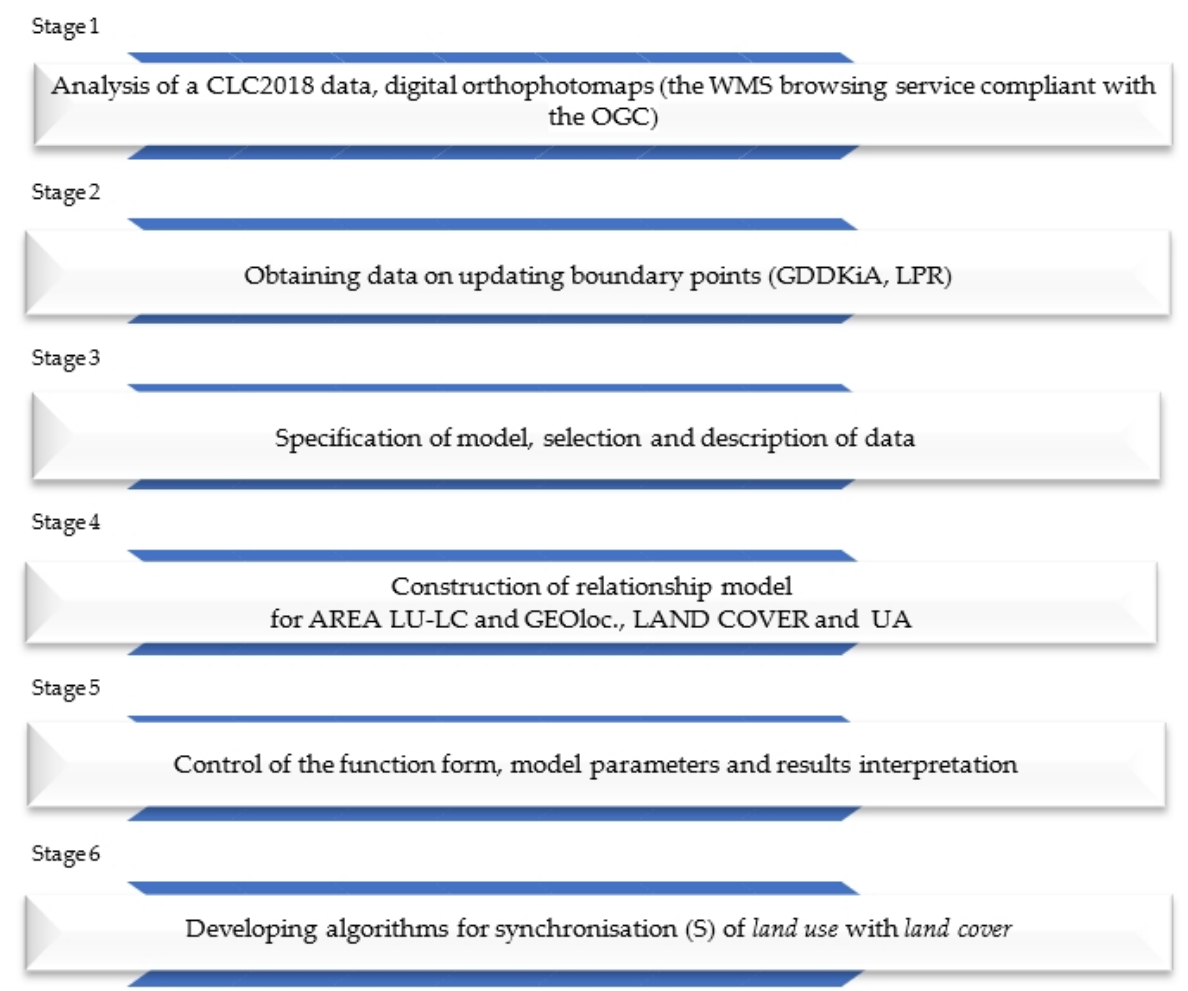

Figure 5. Stages of research. Source: Own study. Abbreviation: CLC2018-Corine Land Cover data from 2018; WMS-Web Map Service; OGC-Open Geospatial Consortium; GDDKiA - General Directorate for National Roads and Motorways; LPR—Land and Property Registry; LU-LC—the difference between land use and land cover; UA—the area urbanization.

The model of the relationship between the independent variables and the dependent variable (AREA LU-LC) was based on the hedonic regression analysis. This model was based on the assumption that heterogenic factors can be described with individual characteristics or their attributes [59-62]. Therefore, hedonic regression models can be used to assess how individual attributes affect the final area change index. This means that the final difference (AREA LU-LC) depends on a combination of individual characteristics, which-for the model under study-include such attributes as the land cover (LAND COVER), location of discrepancies (GEOloc.) and the level of urbanisation of the surroundings where the discrepancy existed (UA). Three types of function forms-linear, logarithmic and logarithmic-linear-are often used in empirical analyses which employ hedonic regression models [63]. The type of function form depends on the distribution of variables in the model. Several researchers prefer to use the so-called semi-logarithmic model for different reasons [64,65]. One reason given is that the semi-logarithmic model coefficients can be interpreted as the percentage change of the independent variable $[59,66]$. The selection of the function form was based on the fitting criterion 
(determination coefficient), the efficiency of regression coefficient interpretation and the Akaike information criterion [57,58] (see Equation (3)). These models can be expressed in the following form:

$$
\begin{gathered}
V_{i}=\beta_{0}+\beta_{i j} Z_{i j}+\cdots+\varepsilon_{i}, \\
V_{i}=\ln P_{i}, \beta_{0}=\ln a_{0}, \beta_{i j}=\ln a_{i j},
\end{gathered}
$$

where $P_{i}$ is the measured area in a different way than the road for the user under study, $Z_{i j}$ is the vector of attributes affecting the differences, $a_{i j}$ is the vector of the associated coefficients to be estimated and $\varepsilon_{i}$ is the vector of error terms. Attributes were selected based on deduction arising from data analysis and detailed verification of each discrepancy location. The analysed variables are described in Table 1. The effect of independent variables was interpreted $[33,66]$ according to Equation (2), which allowed for determination of the percentage effect of each attribute under study on the final area discrepancies:

$$
W_{i j}=\left(\exp \cdot a_{i j}-1\right) * 100,
$$

where $W a_{i j}$ is the importance of an attribute, and $a_{i j}$ is the regression coefficient.

The Akaike information criterion $[57,58]$ is presented by Equation (3):

$$
A I C=n * \ln \left(\sum_{i=1}^{n} e_{i}^{2}\right)+2 k
$$

\begin{tabular}{|c|c|c|c|c|c|}
\hline Attribute & Description & Aver. & Min. & Max. & Sdev. \\
\hline AREA LU-LC $*$ & $\begin{array}{l}\text { LU-LC discrepancy area [1-to } 100 \mathrm{~m}^{2} ; 2-101 \text { to } \\
200 \mathrm{~m}^{2} ; 3-201 \text { to } 300 \mathrm{~m}^{2} ; 4-301 \text { to } 400 \mathrm{~m}^{2} ; 5-401 \text { to } \\
\left.500 \mathrm{~m}^{2} ; 6 \text { - over } 501 \mathrm{~m}^{2}\right]\end{array}$ & 0.31659 & 0.00 & 1.79176 & 0.5821 \\
\hline UA & $\begin{array}{l}\text { Urbanisation level of the area in which the discrepancy } \\
\text { exists LU-LC [1-town; } 2 \text {-rural built-up area; } \\
\text { 3-non-built-up area outside a town or village] }\end{array}$ & 1.7163 & 1.00 & 3.00 & 0.6842 \\
\hline LAND COVER & $\begin{array}{l}\text { Land cover [1-plot fence/stairs to a building/pavement } \\
\text { leading up to a building/building/etc.; } 2 \text {-fence around } \\
\text { a property with a part used for home vegetable or } \\
\text { flower garden, or lawn; } 3 \text { - arable land] }\end{array}$ & 1.6275 & 1.00 & 3.00 & 0.7302 \\
\hline GEOloc. & $\begin{array}{c}\text { Number of national roads on which a discrepancy } \\
\text { occurred [DK } \\
\text { DK } 57, \text { DK 58, DK 59, DK 63, DK 65] }\end{array}$ & & 15. & 65. & \\
\hline
\end{tabular}

where: $n$ - numer of observations, $k$ - numer of parameters, $e_{i}$ - the rest of the model for the i-th observation.

Table 1. Primary statistical data of the model, together with an attribute description.

\subsection{Data Collection}

At the initial stage of the study, Corine Land Cover 2018 data derived from the Copernicus Land Monitoring were used. For the construction of the CLC2018 base, the imagery from Sentinel-2 and Landstad-8 satellites with the resolution of $100 \times 100 \mathrm{~m}$ was used. For detailed analyses, the following were used the digital orthophotomaps shared under Directive 2007/2/EC of the European Parliament of the European Union on infrastructure of spatial information [67] operating under the Web Map Service browsing service (compliant with the OGC standards) with a pixel ranging from 0.5 to $0.25 \mathrm{~m}$, the results of the geodetic update of boundary points, performed by specialised geodesist teams (obtained from GDDKiA) and cadastral data (obtained from LPR). Table 1 presents a description of LU-LC inconsistencies used in the statistical model.

\section{Results}

The first stage of the study indicated nine road sections where the most cases of LU-LC inconsistencies occurred. The results of the geodetic update of the national road boundaries and 
orthophotomaps were analysed for detailed interpretation of inconsistencies. Each case of LU-LC discrepancy was referred to the current user of the part of the right-of-way. This means that when several plots included in a right-of-way were used by one person or a group of persons, the areas of the plots were added up. The analyses showed that land use was different than the land cover in 349 cases. The highest number of cases (88) was on the national road DK 65, and the lowest (4) was on the national road DK 63 (see Figure 6).

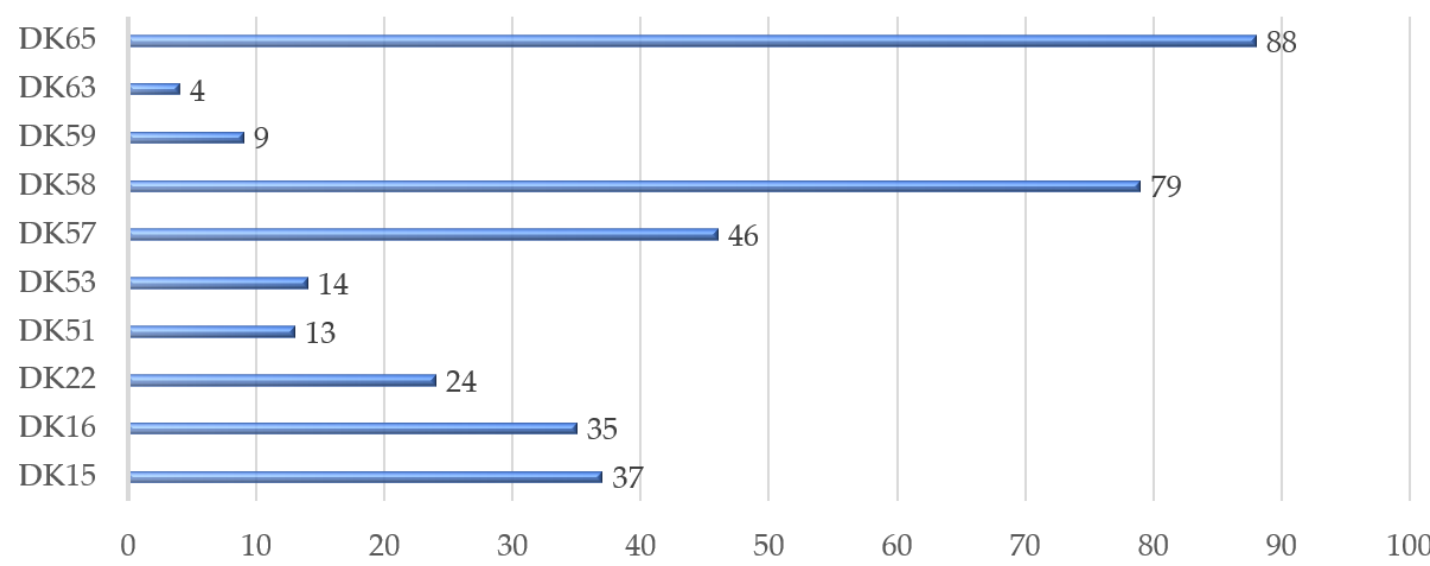

Figure 6. The number of examined LU-LC discrepancies in the area under study. Source: Own study on [68].

The area of all the LU-LC discrepancies was $64,885 \mathrm{~m}^{2}$. The smallest area of a discrepancy was $1 \mathrm{~m}^{2}$ and there were 18 such cases. The largest area of a discrepancy was $9990 \mathrm{~m}^{2}$ and it was situated on the national road DK 22 near the village of Mojkowo (Elblag comune). Figure 7 shows the area distribution for all the LU-LC discrepancies.

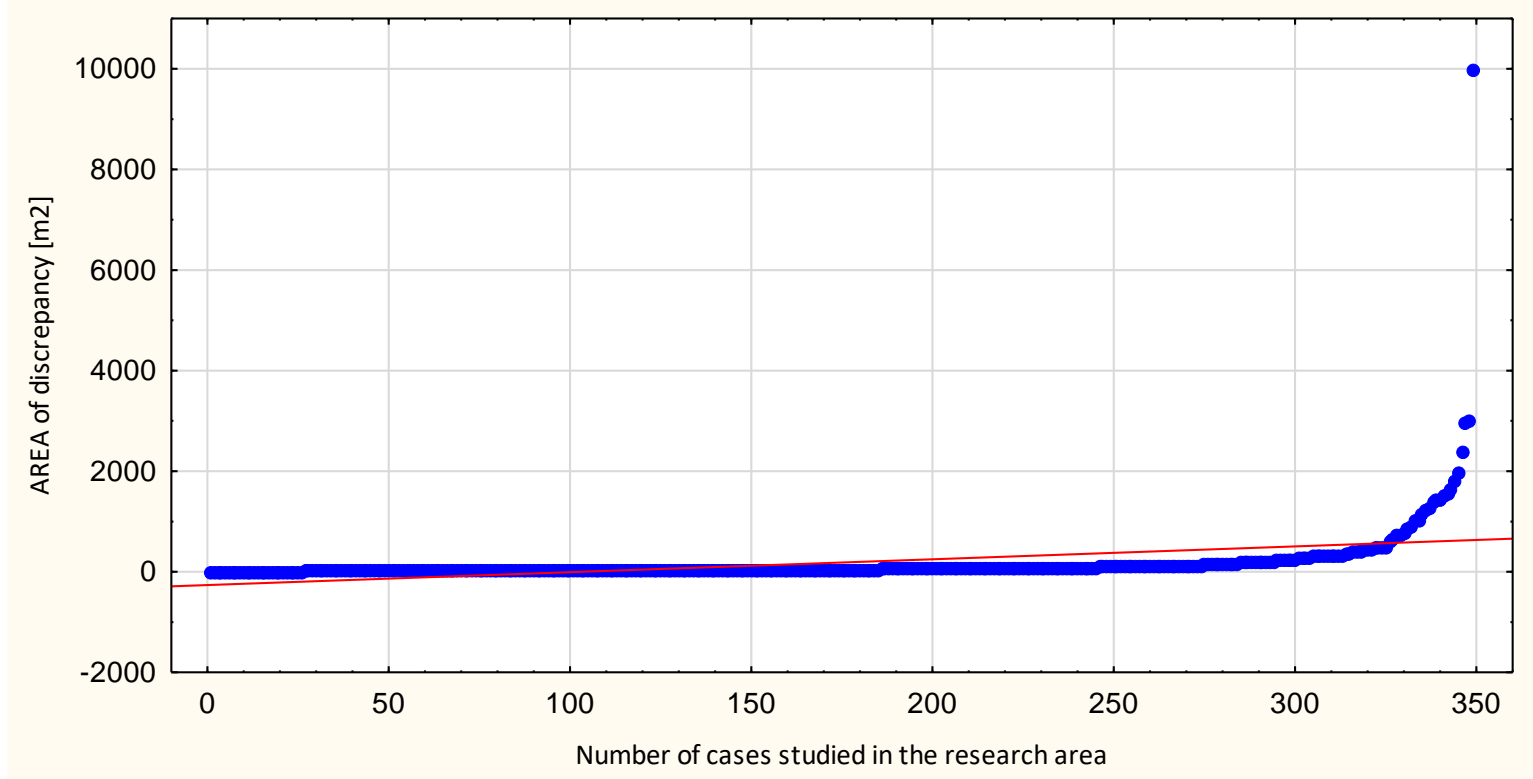

Figure 7. The area distribution for all the LU-LC discrepancies. Source: Own study on Statistica 13.1.

In total, $42 \%$ (145) of LU-LC discrepancies were situated within the administrative borders of towns, $45 \%$ (158) in built-up rural areas, and 13\% (46) in non-urbanised areas (outside areas of compact housing development). An LU-LC discrepancy usually involved an incorrectly constructed fence around a property; there were $46 \%$ of such cases and they covered a total area of $3418 \mathrm{~m}^{2}$. In $33 \%$ of 
the LU-LC discrepancies, some land was taken over for a fence and a vegetable/flower garden or a lawn. In this manner, a total of $15,012 \mathrm{~m}^{2}$ of land was developed. In $14 \%$ of LU-LC discrepancies, the land was used for crop growing. Unlike in the other LU-LC discrepancies, arable land occupied as much as $44,983 \mathrm{~m}^{2}$. In $5 \%$ of LU-LC discrepancies, the land was occupied by stairs or a concrete pavement leading up to a building. The area of the occupied right-of-way was $823 \mathrm{~m}^{2}$. The other LU-LC discrepancies (2\%) included land occupied by buildings and forest/afforested land, whose area was 214 and $435 \mathrm{~m}^{2}$, respectively.

The impact of the attributes on the emerging LU-LC discrepancies was examined using the hedonic regression model. The form of the model was selected based on the distribution of variables, determination coefficient value, the effectiveness of the regression coefficient interpretation, and the Akaike criterion $[57,58]$. The estimation of regression parameters was carried out by the least squares' method. Hedonic regression model included four variables: the discrepancy area (AREA LU-LC), geolocation (GEOloc.); type of land cover (LAND COVER) and the urbanisation level in the area (UA) where an LU-LC discrepancy exists (see Table 1). The choice of attributes was based on deduction during the data accumulation and geo-location analysis for each case. Since the F-test for four independent variables and $345(\mathrm{~N}-\mathrm{m}-1)$ cases equalled $\mathrm{F}=175.29$, the hypothesis that regression coefficients are not statistically significant was rejected, and an alternative hypothesis was adopted. The multiple correlation coefficient for the model, which determines the total impact degree of all explaining variables on the explained variable is $\mathrm{R}=0.7770$. Since the log-linear model explained $60 \%$ of the total variance in the dependent variable $(\mathrm{R} 2=0.6003)$, the model was; therefore, sufficiently fitted to the data (see Table 2). It should be noted that the model takes into account all the observed and calculated cases of discrepancy, without rejecting any user of ground under analysis. Independent (explaining) variables describing the model are statistically significant at $\alpha=0.05$, they do not exhibit co-linearity (after performing the correlation matrix analysis).

Table 2. Modelling results.

\begin{tabular}{ccccc}
\hline \multicolumn{5}{c}{ Log-Linear Model } \\
\hline Independent Variable & Coefficient & Sdev. & t-Student & $\mathbf{p}$ \\
\hline CONST. & -0.826942 & 0.072589 & -11.3921 & 0.0000 \\
LAND COVER & 0.481197 & 0.029735 & 16.1831 & 0.0000 \\
UA & 0.274247 & 0.031250 & 8.7759 & 0.0000 \\
GEOloc. & -0.002298 & 0.001031 & -2.2280 & 0.0265 \\
R & 0.777070 & & & \\
Adjusted R & 0.600398 & & & \\
Number of observations & 349 & & & \\
F(3, 345) & 175.29 & & & \\
\hline
\end{tabular}

Source: Own study on Statistica 13.1.

LU-LC synchronisation requires administrative and legal proceedings, whose procedure and course depends on the land cover. Following are eight algorithms which can be used for LU-LC synchronisation within the right-of-way boundaries. Both the subject (the person who took over the right-of-way) and the object (type of land cover) which caused the lack of LU-LC synchronisation were taken into account.

\subsection{The Right-Of-Way Occupied by Objects Erected by Individuals/Legal Entities/Associations/Unions/Other Legal Entities}

\subsubsection{Objects Erected before 1985}

The right-of-way boundaries can be violated by other entities/persons purposefully or inadvertently. The land cover analyses have shown that there are situations when a residential/industrial/sacred (or rather its fragment) building or an element associated with a building (e.g., retaining wall, stairs, cornices, etc.) is situated within a right-of-way. Removal of such parts of objects can make the buildings 
unusable. Figure 8 shows an example a fragment of an orthophotomap, on which a corner of a building cuts into the right-of-way and the area shaded with red colour indicates a sketch from the survey on the ground, where one can see a structure serving a building situated within a right-of-way.

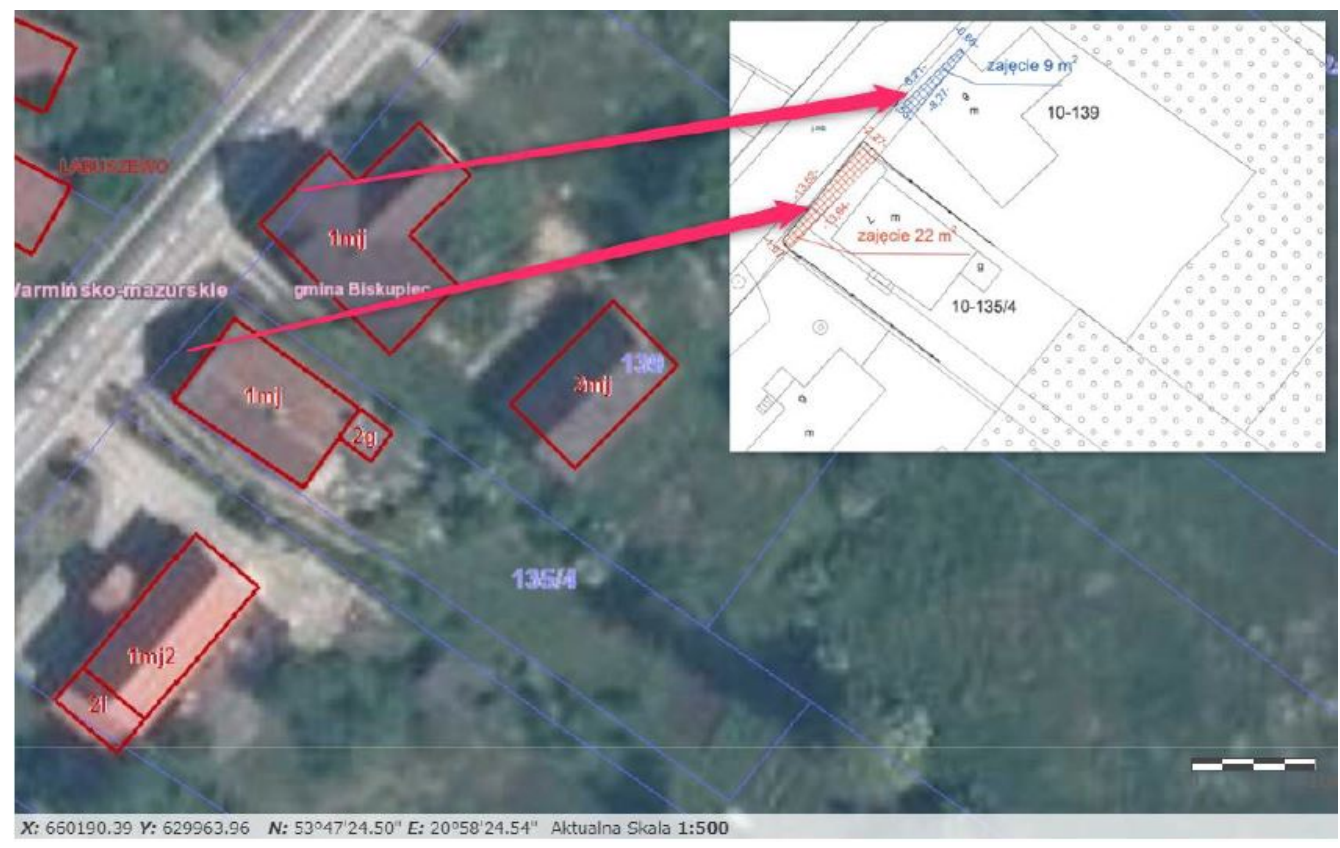

Figure 8. Example building fragment of building (blue colour) and entrance to building (red colour) situated within a right-of-way. Source: $[68,69]$.

For the fragment of a building, the LU-LC synchronisation can be performed by choosing one of two solutions (see Figure 9). The first involves segregation of part of a built-up plot, in accordance with the legal procedure laid down in the Real Estate Management Act (segregation of a built-up part of a plot). When it is applied, a change of land use is entered into the Land and Property Registry (LPR) and the right of permanent administration expires (the right of the road administrator). Subsequently, a civil law agreement of sale/donation of a segregated piece of land is signed; thereby, the LU-LC synchronisation is achieved. Another solution involves leaving a structure within the right-of-way since Art. 38.1. of the Public Road Act allows for such situations: " ... objects that do not pose a threat or hinder the road traffic nor do they disturb the process of performing the tasks of the road administrator can be left unchanged ..." [37]. Leaving such an object as it is does not require any confirmation or permit for the object to remain at the place [70]. The solution for an object built after 1985 is shown in Figure 9.

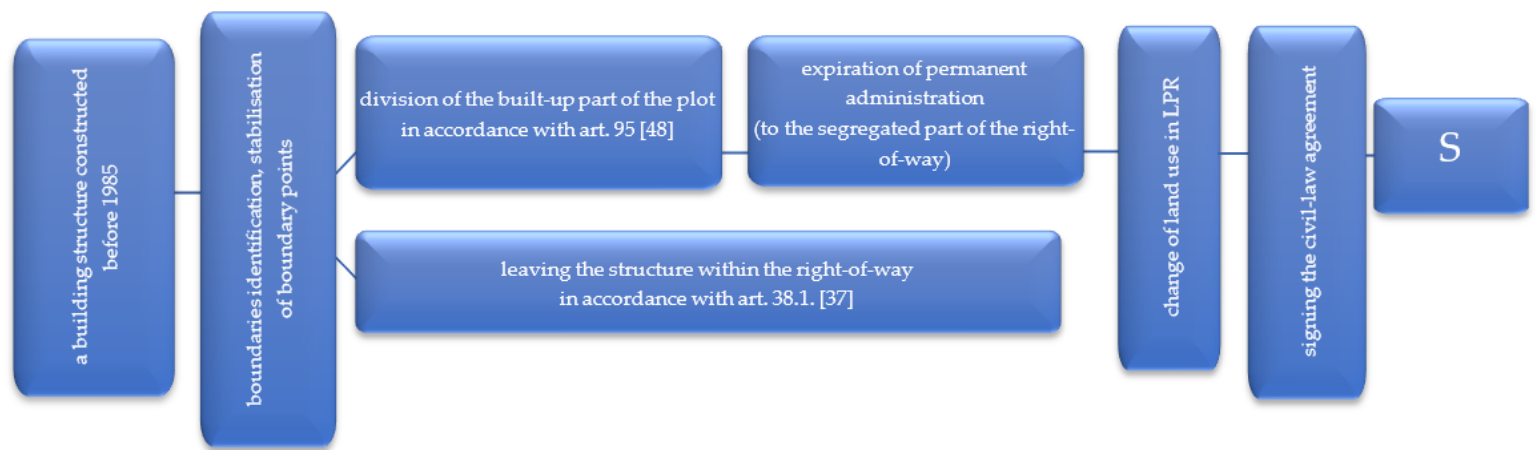

Figure 9. Algorithm of LU-LC synchronisation (acr. S) for objects constructed before 1985. Source: Own study. 
4.1.2. Occupation of a Right-Of-Way by a Fence, a Gate (Constructed in Accordance With/In Violation of the Valid Legal Procedures)

A fence around a plot or a gate constructed within a right-of-way is a frequent case of violation of administrative boundaries Figure 10 shows a portion of the right-of way occupied by a person (the owner) who uses the adjacent area. The green line indicates the right-of way boundary, while the shaded area shows the misused right-of-way area.

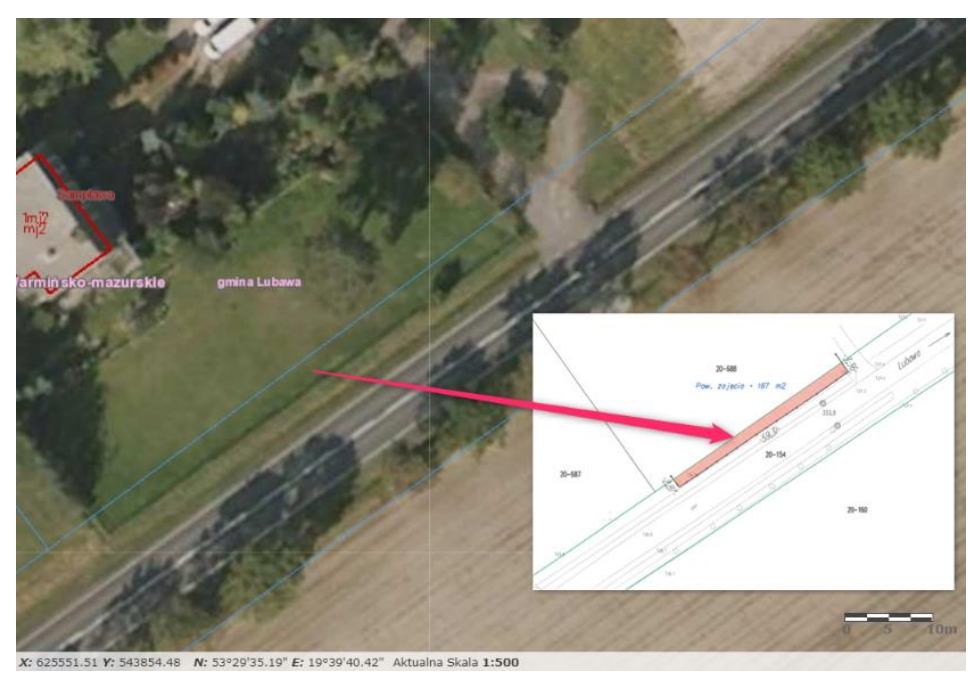

Figure 10. Example field sketches from measurements on the ground showing a fence made within a right-of-way (owned by an individual). Source: [68].

Currently, the body that administers a right-of-way, having found out that there is a fence, sends an official letter to the investor ordering them to restore the right-of-way to the previous state [71], which implies that it has to be demolished or moved. If this is not done within the time limit set by the officials, the administrator escalates the issue to the construction supervisory body (architectural and construction administration body). This body verifies whether the fence was constructed in line with the valid regulations. Regardless of whether the fence was built under a building permit (e.g., when it borders on an historic object) or without such a permit, a demolition order is issued as an administrative decision [72]. The fence owner/investor must move or remove the fence within the set time limit so that it is situated outside the right-of-way. Otherwise, the owner/investor will pay a fine for non-contractual occupation of the right-of-way [37]. Apart from the road administrator, the fence owner can also apply for a permit to demolish the fence (see Figure 11). If a building permit/notification was not required for the fence construction (for fences lower than $2.2 \mathrm{~m}$ ), the structure owner can move/remove the fence outside the right-of-way without the demolition decision. The LU-LC synchronisation takes place after the previous land arrangement is restored (Figure 11). 


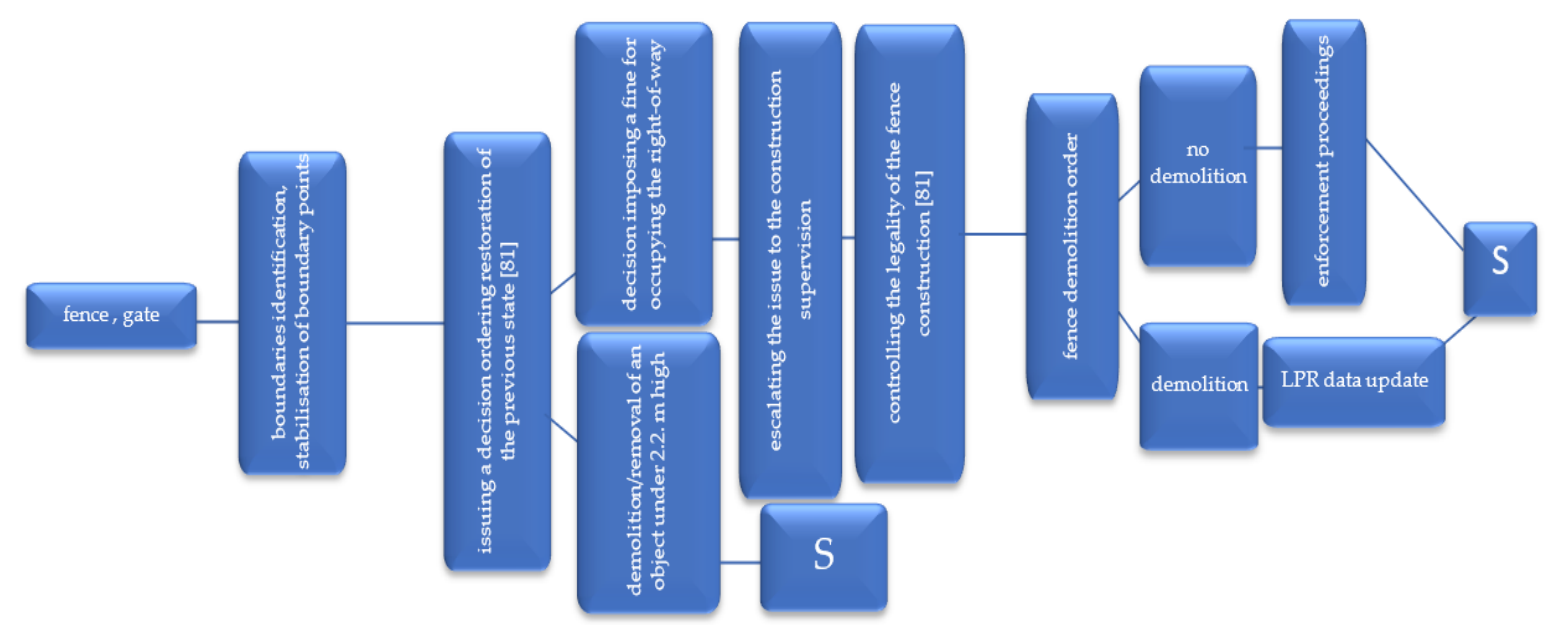

Figure 11. LU-LC synchronisation algorithm for a fence/gate built within a right-of-way. Source: Own study.

\subsubsection{Technical Infrastructure Devices within a Right-Of-Way}

There may be equipment serving the passenger, the right-of-way, equipment supporting the right-of-way administration and equipment unrelated to the road located within the right-of-way (if they do not interfere with the traffic handling) [37]. For devices located within a right-of-way which are used for the road operation, a lease/rent or loan agreement is signed [37]. Lease/rent agreements involve payment of rent, whereas a loan is free of charge. The choice of an agreement is a consequence of the object type, its function and the person (investor) who constructed the device (e.g., local governments, public-private partnership, etc.). For example, no fees are collected for constructing the pavement lighting by a local government (commune) within the national road right-of-way in an area with housing development [73]; it is the opposite with passenger service facilities, such as petrol stations, parking spaces or restaurants, for which fees are collected [37]. Technical infrastructure devices unrelated to the road operation (e.g., power cabinet, telecom cabinet, etc.) can be constructed after obtaining a permit to occupy a right-of-way. An investor also has to pay annual fees for placing a device within a right-of-way [37]. A lease/rent/loan agreement or a permit to occupy a right-of-way ends the LU-LC synchronisation process (see Figure 12).

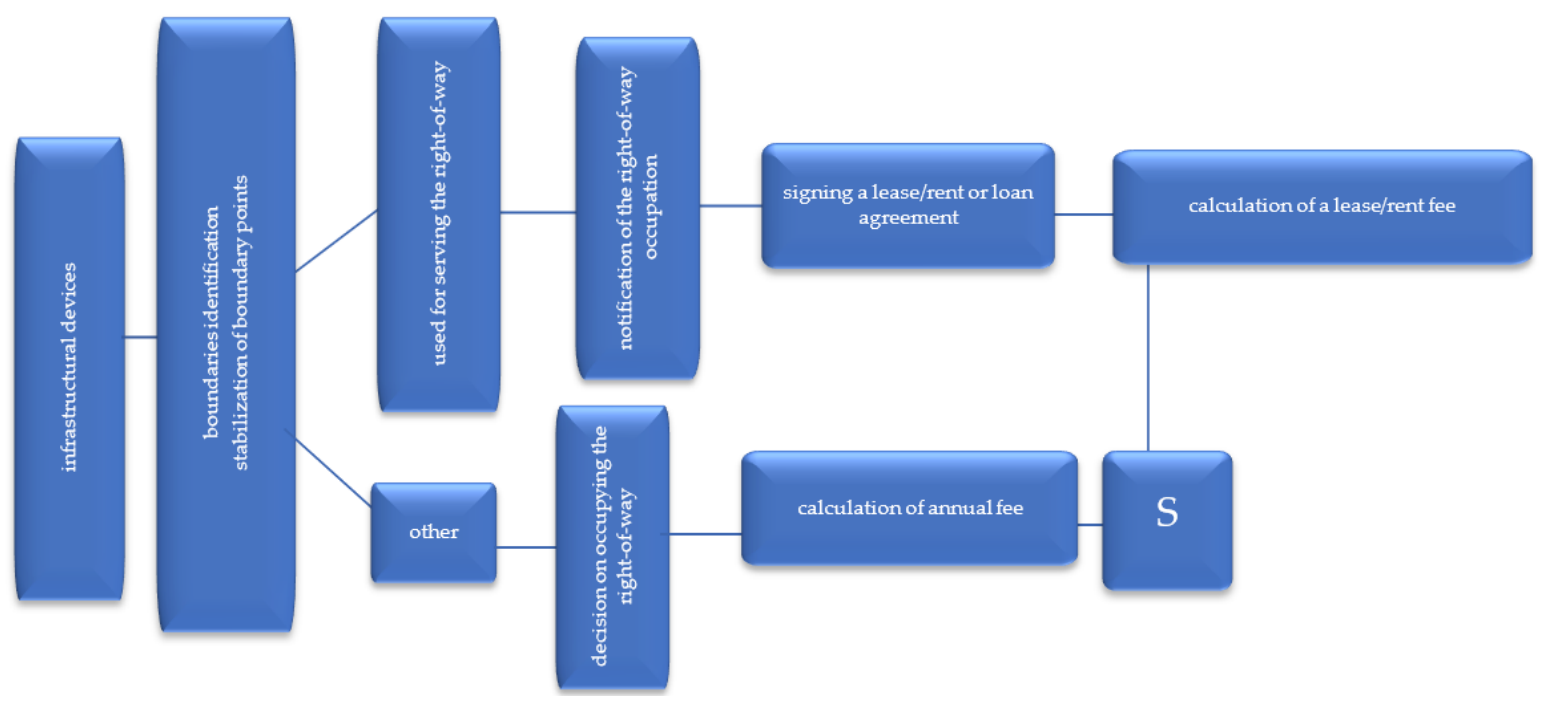

Figure 12. LU-LC synchronisation algorithm (acr. S) when technical infrastructure devices are located within a right-of-way. Source: Own study. 


\subsubsection{Advertisements within a Right-Of-Way}

Placing an advertisement within a right-of-way (see Figure 13) requires a permit allowing one to occupy a right-of-way and the payment of two kinds of fees. The first is paid in connection with mounting and putting up an advertisement $[37,74]$ and the other is a kind of tax for interference with the landscape (advertisement fee) [75,76].

If the advertisement owner does not have the relevant documents, they pay a fine for illegal occupation of the right-of-way (10 times the amount of fee) and the time limit for its payment. The object must be removed after the set deadline and restore the right-of-way to its previous state consistent with the LPR [71]. If the investor fails to respond appropriately, administrative enforcement proceedings are conducted (exercising the rights/obligations arising from the civil law agreements) (see Figure 13).

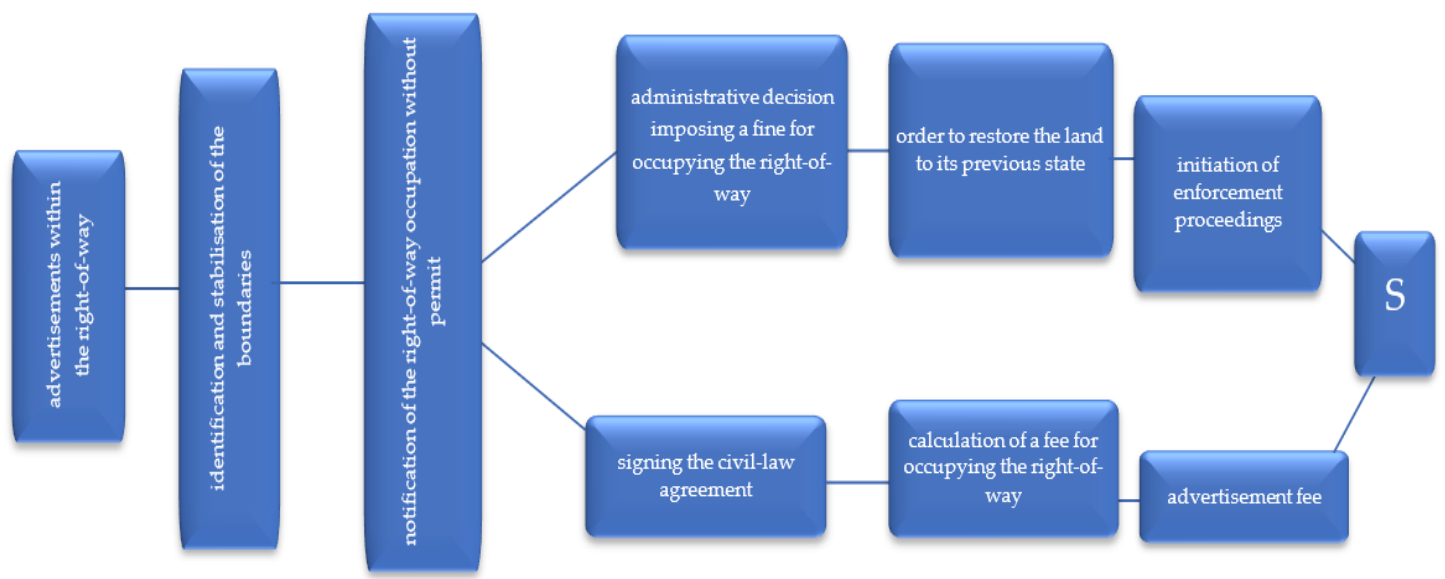

Figure 13. Algorithm of LU-LC synchronisation (acr. S) for an advertisement placed within a right-of-way. Source: Own study.

\subsubsection{Crop Growing within a Right-Of-Way}

LU-LC synchronisation in cases when a right-of-way is used as arable land is one of the simplest algorithms. Figure 14 shows a portion of the right-of-way that is used for growing agricultural crops.

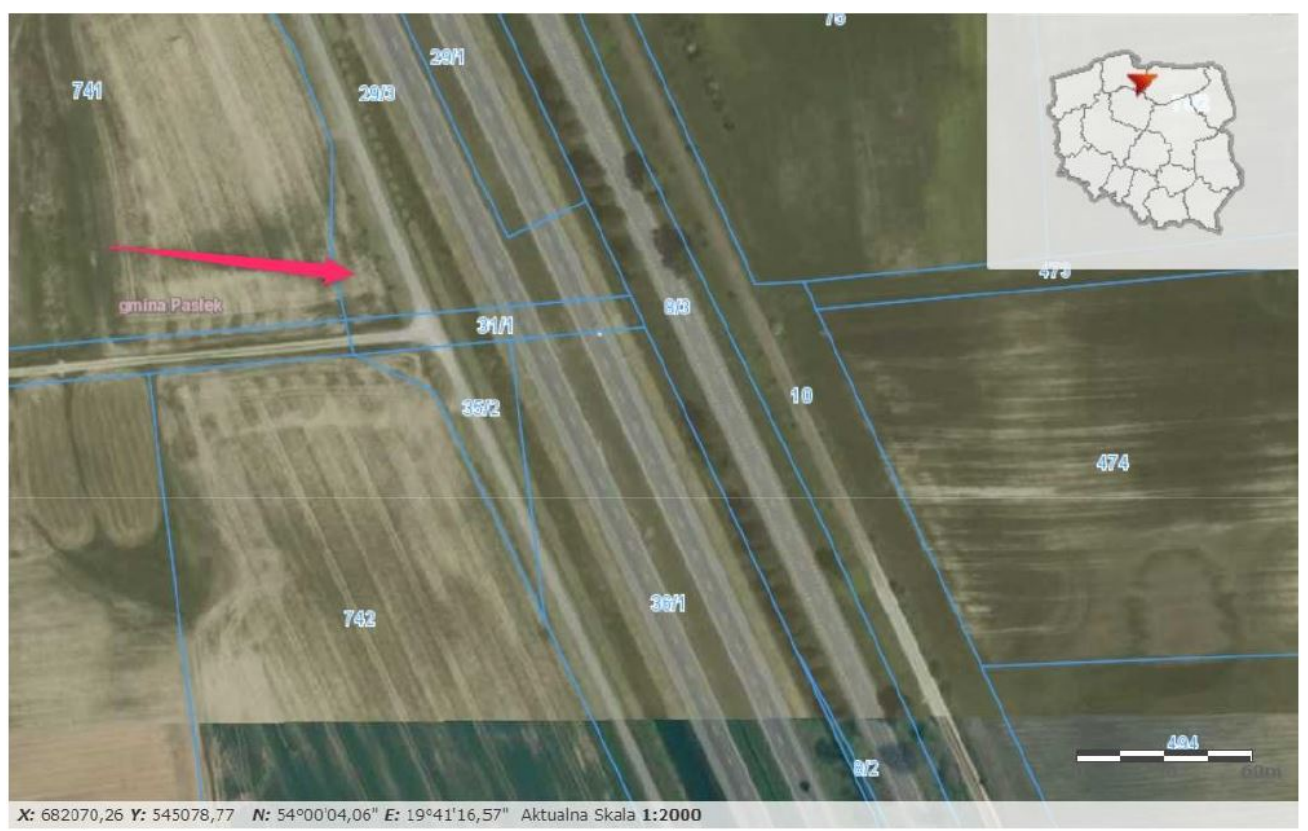

Figure 14. Fragments of orthophotomaps showing cases of using a right-of-way as arable land. Source: [69]. 
In such cases, when the farmer-crop owner-is informed, he removes the crop from the piece of land which is not his. If, after identifying the border and the right-of-way stabilisation, the farmer still uses the land in an unauthorised manner, fines are charged for occupying a right-of-way without permit (10 times the usual fee for occupying a right-of-way) (Figure 15).

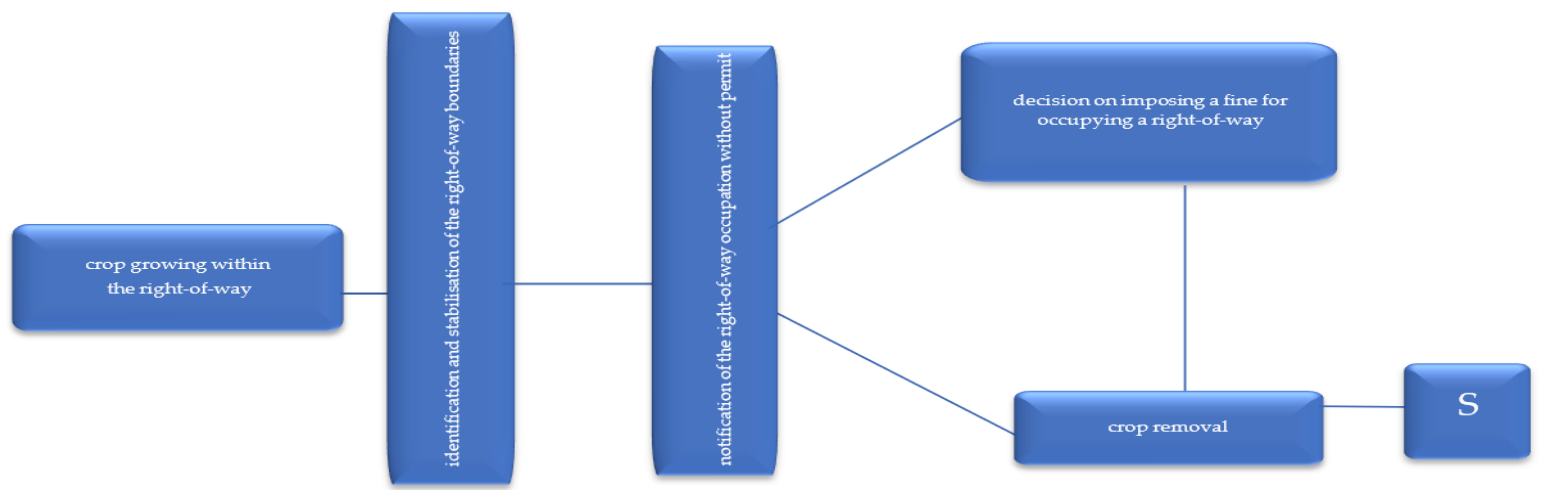

Figure 15. Algorithms of LU-LC synchronisation (acr. S) when a crop is being grown within a right-of-way. Source: Own study.

\subsubsection{A Home Garden, an Orchard, an Afforested Area/Forest within a Right-Of-Way}

The LU-LC synchronisation procedure when there is an orchard/garden/forest within a right-of-way involves identifying the time when they were established and examining whether they pose a threat to traffic. Figure 16 shows a case of the right-of-way occupation by a home garden along with woodlots. On the left, field measurement results are shown; moreover, it is shown what portion of the right-of-way has been occupied by the private owner who owns the adjacent area (we can see the home garden and the fence). To perform LU-LC synchronisation, the determination of the time of the establishments of the elements in the right-of-way that are not used for its operation (time when the fence was build and tree planting). This date is of prime importance because if they were established before 1985 and they interfere with the performance of their tasks by the road administrator, they cannot remain within the right-of-way. All the objects established after 1985 have to be removed from the right-of-way. It is not easy to establish the date when an orchard/garden were created and one has to have documentation confirming that the land has been used in this manner for over three decades (photographs, residents' statements, other documents, etc.).

An opinion of an expert in gardening and horticulture is required. Leaving an orchard as it is does not require any confirmation or permit for it to remain in the right-of-way [70] and LU-LC synchronisation occurs. The situation is more complicated when the orchard makes the road administration difficult. Removal of the trees and other objects from the right-of-way is the only solution. No permit is required in Poland to remove fruit trees [77]; such a permit/notification is required for other types of trees.

If a right-of-way user fails to abide by the decision issued by the road administrator, penalties are charged for non-contractual occupation of the right-of-way (until the trees are removed from the right-of-way).

The situation is different for afforested areas within a right-of-way. Trees within a right-of-way are owned by the state/local government, and the road administrator is obliged to remove them if they pose a threat to traffic safety. The administrator is obliged to obtain a permit for tree removal if they are not fruit trees. If branches of trees growing outside the road hang over the right-of-way, the tree owner is informed, and an agreement is reached about who will remove the tree. It is usually done by specialist services ordered by the road manager. Figure 17 shows an LU-LC synchronisation algorithm if an orchard, home garden, etc. is situated within a right-of-way. 


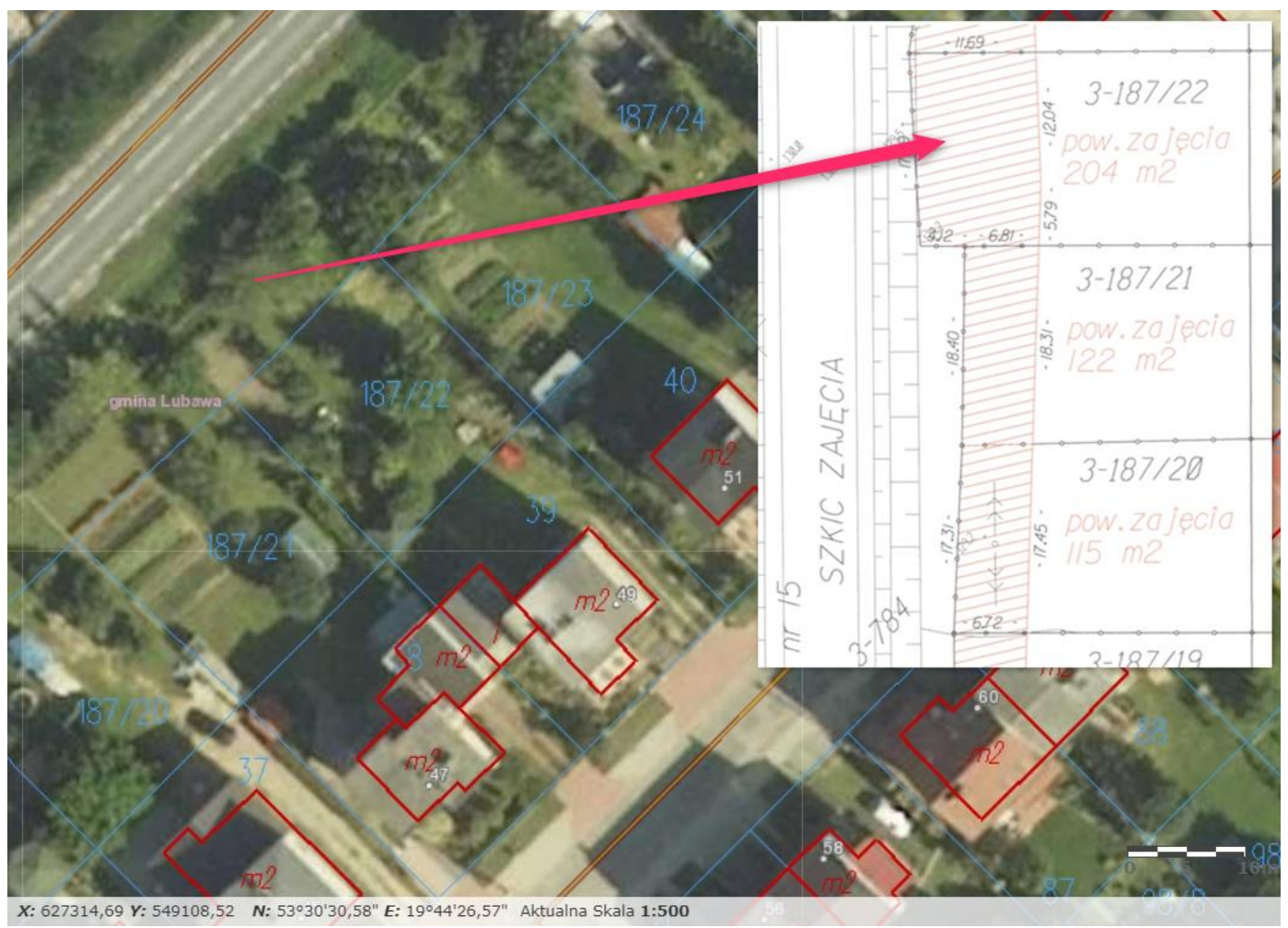

Figure 16. Orthophotomaps with the land cover and land use (results of the measurements). Source: $[68,69]$.

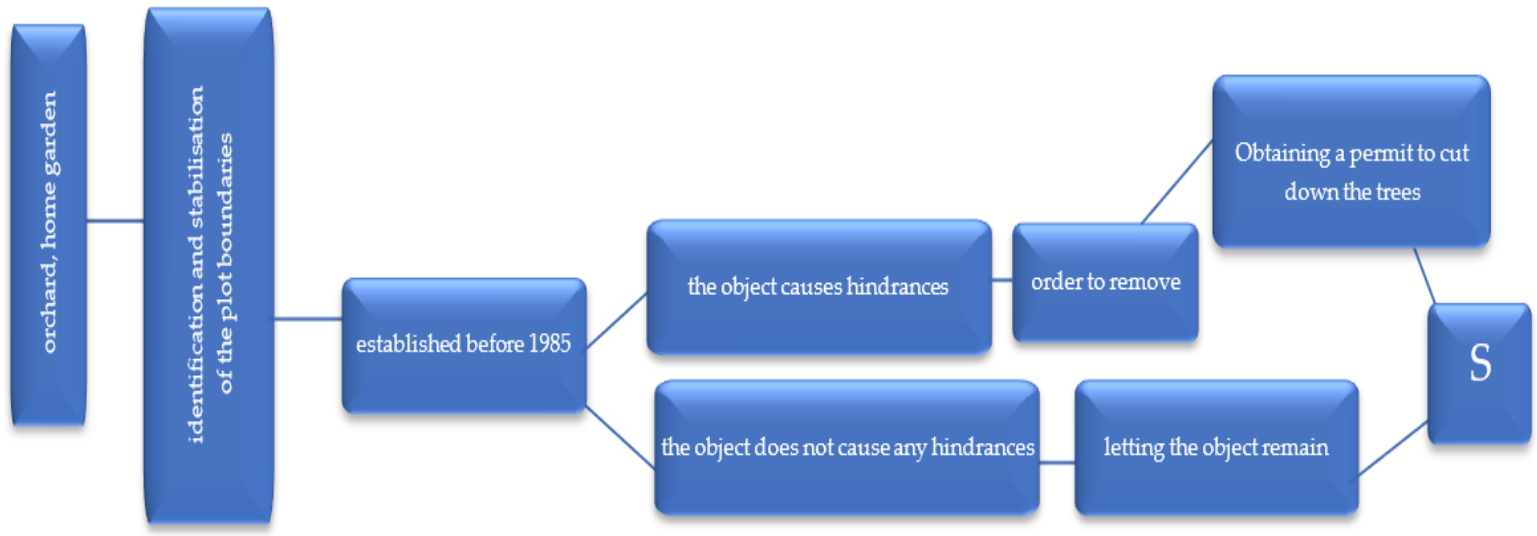

Figure 17. An LU-LC synchronisation algorithm with an orchard, a home garden and afforested areas as examples. Source: Own study.

\subsection{Land Owned by Individuals/Legal Entities Occupied by Public Roads and Associated Devices}

An LU-LC synchronisation should also be performed when a roadway or traffic handing devices were constructed on land owned by an individual/legal person. This applies mainly to objects constructed before the political transformations that took place in Poland in the early 1990s. When private land was taken over by a road used for public purposes in 1998, it was acquired by the relevant local government unit or by the state treasury by virtue of the law (see Figure 18). A decision was issued to confirm the fact. Private land taken over for a road constructed after 1999 is viewed differently. This could happen because the construction law allowed for execution of a construction project on land held (rather than owned) by the investor. The right-of-way updates revealed the existence of bus lay-bys, a retaining wall and a draining ditch, etc. constructed on private land. LU-LC synchronisation can be performed in two ways. The first (the simplest) is when the owner agrees to segregate the object (e.g., the draining ditch) and to allow for the land buyout. The situation is more difficult when the 
owner does not want to sell the piece of land occupied by the road devices. Two options are considered in such cases. The first option involves transferring the devices without exposing them to the risk of damage. It is possible in the case of a lamppost, or a post powering cabinet, but not possible in the case of a retaining wall or a draining ditch. Lack of possibility of a device transfer from a specific location makes the road administrator bring the case to court (in a civil case) so that the court decides how the issue should be solved. The case is finally settled after the court issues its decision. 


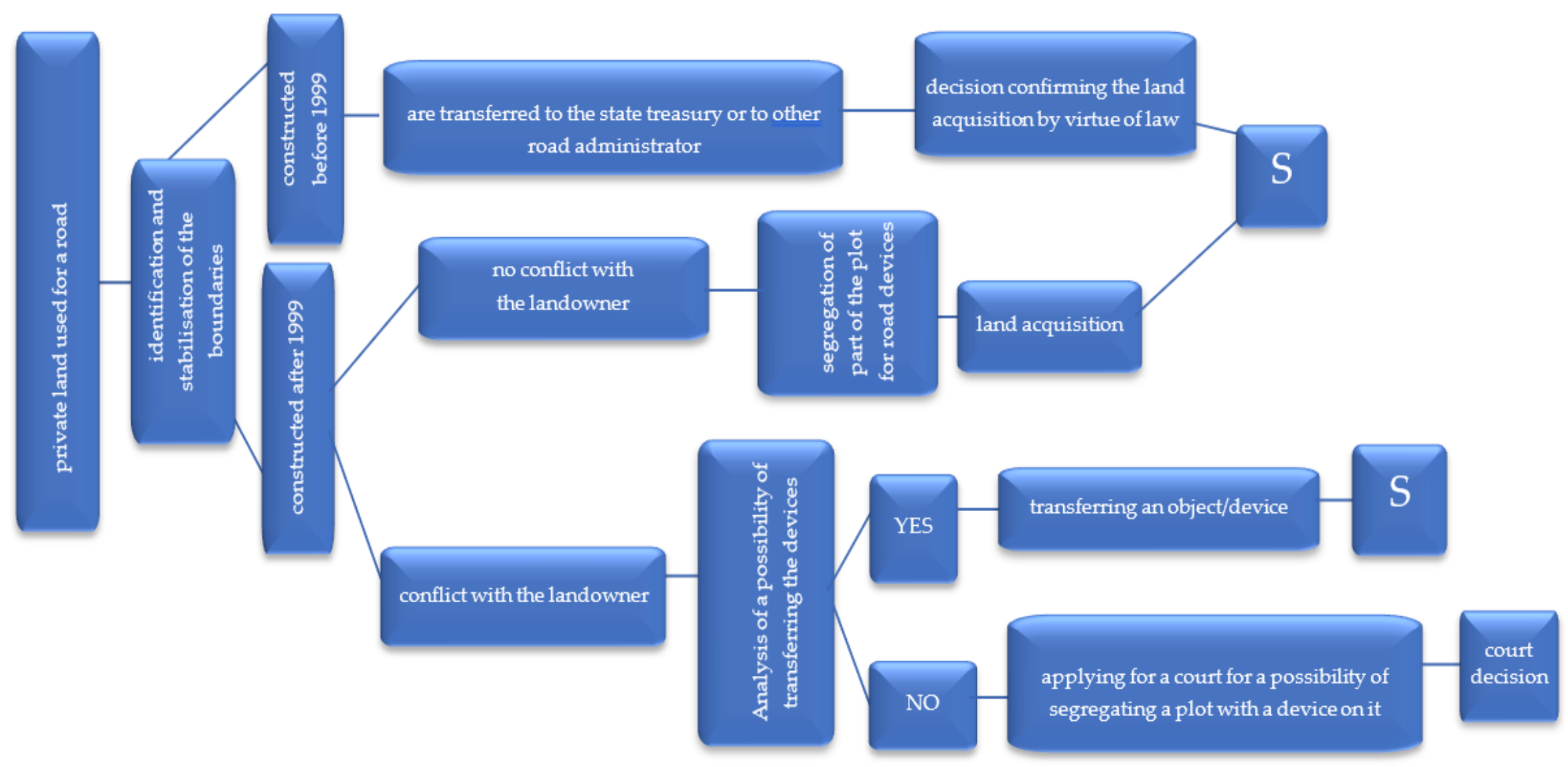

Figure 18. An LU-LC synchronisation algorithm (acr. S) for private land taken over for a road or traffic handling devices. Source: Own study. 


\subsection{Land Taken over by Local Government Units (State Treasury/Commune/County/Voivodship) Other Than the Road Administrator}

National roads in Poland can be owned by the State Treasury and other roads can be owned by respective local governments. These relations are discussed in detail in Section 2 (Background). A problem may appear in some situations when fragments of a national road are used by local governments (voivodship/county/commune) for their economic purposes. In such cases, the correctness of the property communalisation decision issuance process is first controlled [78,79]. If a road fragment meets all the recommendations laid down in the law, then a disputable part is segregated [48] and donated to the state treasury. A defective communalisation decision, issued when the road fragment did not meet the statutory conditions, is repealed and a new one is issued, with consequent LU-LC synchronisation (see Figure 19).

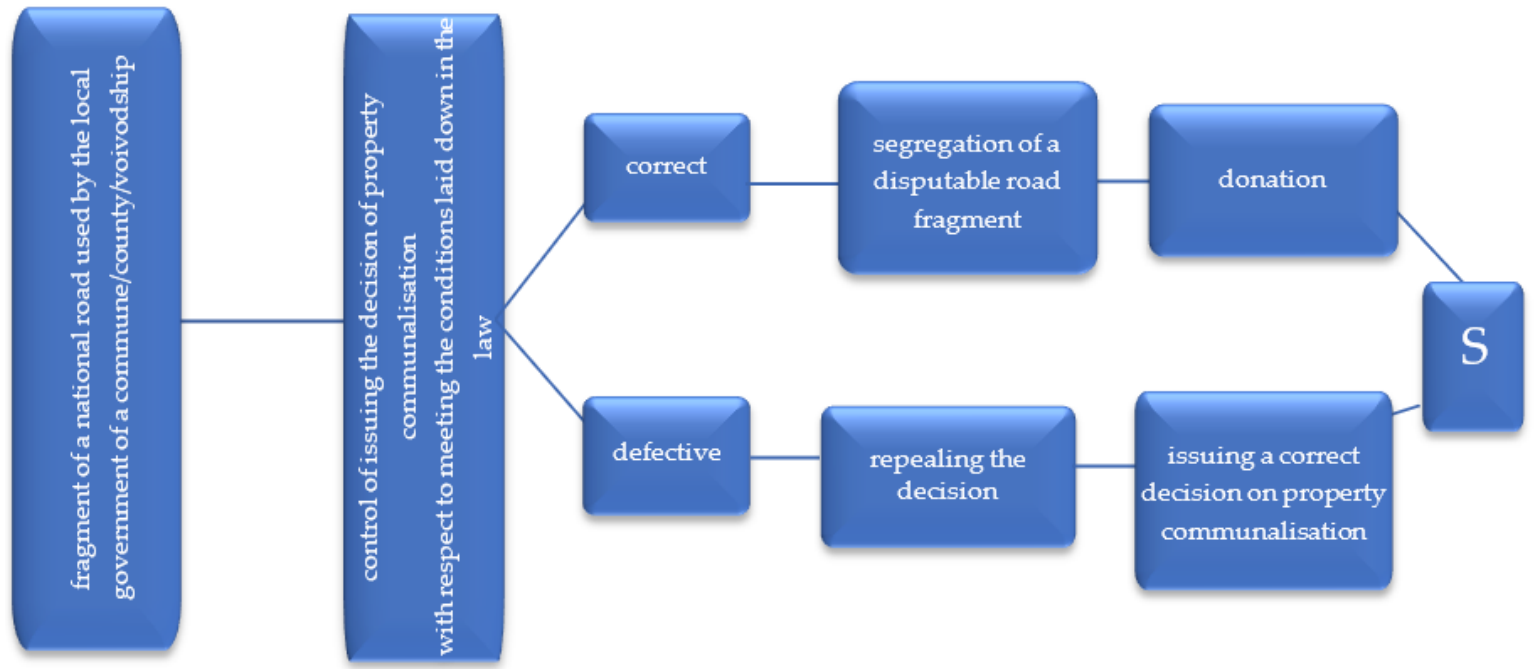

Figure 19. Algorithm of LU-LC synchronisation for a national road taken over by the commune/county/voivodship local government. Source: Own study.

\section{Discussion}

The aim of the study was to analyse the discrepancies between land use and land cover existing within a right-of-way. The sections of national roads under study were selected based on the results of analysis of CLC2018 and cadastral (LPR) data. It was found that within the right-of-way boundaries, the ranges of three other ways of land cover were included (1.1.1: Continuous urban fabric; 2.4.1: Pastures; 2.4.3: Land principally occupied by agriculture with significant areas of natural vegetation). Each case of the LU-LC discrepancy was then photo-interpreted using an orthophotomap and results of the right-of-way geodetic update. This helped obtain information on the actual land cover status. The detection indicated that the following components of land cover are found within the right-of-way: A plot fence, vegetable and flower gardens, home lawns, land under agricultural cultivation, wooded areas, and components associated with buildings (a building corner, pavement, ones used for the operation of building, stairs, etc.). The hedonic regression model being constructed took into account the discrepancy area (AREA LU-LC), the land cover (LAND COVER), surrounding urbanisation level (UA) and the geolocalisation (GEOloc). The number of variables adopted for the model resulted from substantive reasons and the availability of data. The high F-statistics value (175.29), the corresponding probability level $(\mathrm{p}<0.0001)$, the determination coefficient level and the Akaike information criterion (the semi-log function was of the lowest AIC value) confirmed the statistical significance of the adopted model and the correctness of the selected function form (see Supplementary 1).

The hedonic regression model demonstrated that all the attributes under study were statistically significant at the confidence level $\alpha<0.05$ and they affected the discrepancy areas. The model 
fits $60 \%$ of the sample under analysis. The model took into account all observed and measured LU-LC discrepancies.

The area of the emerging LU-LC discrepancies was affected the most by the variables Land Cover and the surrounding urbanization level (UA). A detailed analysis of national roads shows that the size of the area on which the discrepancies exist is affected to the greatest extent by its current cover (LAND COVER) (impact 62\%, assuming the other attributes are constant). This means that the discrepancy areas are the smallest in cases of incorrectly situated plot fences and the greatest when the right-of-way is used by farmers as arable land. The land is tilled with agricultural machines. They are large, which makes the accuracy of ploughing range low, which in turn may result in easy destruction of boundary points [80]. In consequence, the machine operator cannot identify the point where the arable land ends and the right-of-way starts. Fixed elements of a right-of-way, such as a roadway, a pavement, a bridge or a culvert are easily identifiable. It is much more difficult to identify a boundary of a right-of-way when it is overgrown with vegetation and the boundary points were destroyed. It is similar to a boundary between a right-of-way and a forest/afforested land. Trees are usually very invasive species and take over neighbouring areas very easily [81,82], especially when the area is well-lit and humid (draining ditches carrying off water from a roadway provide a lot of moisture). Although modern precision agricultural machines with a GPS receiver are available on the market [83], the percentage of farmers who own such equipment is low because they do not have sufficient funds for such investments [84].

Another equally important cause for LU-LC discrepancies is the way private and state ownership was perceived after the social and political transformations in Poland in 1989-1990. The transfer from planned and social ownership of means of production was replaced with the market economy [85]; it caused some misunderstanding of the definition of the state and private ownership. The "hunger for land" experienced by many Poles during the communist times, led to the situation in which each piece of private land was very valuable, whereas large swathes of state-owned land (after the fall of the communist rule) were seen as "no-one's land". Therefore, individuals eagerly took over pieces of land for their own purposes, such as parking spaces, driveways, lawns, gardens, etc. Road administrators during the communist times and in the early phase of the political transformations focused on road maintenance rather than on identification of their boundaries, because of, among other things, insufficient funds for administration. Currently, this model is changing owing to the funds for updating data on roads, access to new measurement technologies and changes of real estate prices after Poland's accession to the European Union [86,87].

The model developed for the study also demonstrated the validity of the other attribute-urbanisation of the surroundings (UA). The impact of this attribute is $32 \%$ (with the other attributes constant). The smallest area of LU-LC discrepancies was found in urban areas, whereas the largest area was outside the housing developments in rural and urban areas. The area of LU-LC discrepancies grew with increasing distance from the compact housing developments. The level of urbanisation is higher in towns and in areas of compact housing development than in areas outside the town. There are more bitumen roads, concrete pavements, stairs, culverts, bridges, green areas surrounded by curbs, etc. It is a micro-world monitored and controlled by man more frequently than areas with no delimiting features. Crossing a border in an urban area is detected swiftly. A similar relationship can be seen in the developed model. LU-LC discrepancies were smaller in towns and in rural built-up areas and larger in other areas.

The last analysed variable (GEOloc.) also affects the analysed discrepancies. This effect is smaller than with other attributes but still statistically significant (lower than $1 \%$ with the other attributes constant). The number of the national road was used for geolocation. National roads in Poland are divided into sections (one section usually connects two large cities), which are assigned a unique number. By describing an attribute under study in this manner, LU-LC discrepancies were demonstrated on a specific section of a road under study. The index estimated in the model has a 
negative correlation, which suggests larger discrepancies in sections with lower numbers (DK 15, DK 16, etc.), and smaller LU-LC discrepancies in sections with higher numbers (DK 63, DK, 65, etc.).

Apart from model factors which affect the occurrence of LU-LC discrepancies, there are "loopholes" in the regulations. This applies especially to provisions that enable issuing a building permit for a public road [80] on land being at the disposal of an investor. In such cases, when the investor is not the owner and the land was not purchased after the construction process was completed, the land is still owned by the person who provided it. Such LU-LC discrepancies were not identified in the area under study.

When considering the factors that affect LU-LC discrepancies, one cannot leave out the development of modern measurement technologies [20,33], which have a great impact on geodetic surveys. Previous right-of-way surveys were performed several decades ago, when the LPR database was being created or after the road was constructed, with equipment and technologies that were in use at the time. Modern geodetic equipment that is in use nowadays offers much higher accuracy than that in use in the early 20th century. Lack of LU-LC synchronisation is also partly caused by a low number of modernisations of cadastral databases in Poland [19,20,31-33].

The LU-LC consistency is an important attribute, which affects decision-making processes in the road network administration. For example, (a) agreements signed with service providers for the right-of-way maintenance (snow removal in winter, cleaning the roadway in spring, mowing grass in the road shoulders in summer) are based on the state registered in the LPR (land use), which is why the actual land cover should be compatible with it; (b) the body administering the right-of-way is responsible for repair/renovation of a damaged right-of-way, when its fragment is used by other persons contrary to the land use, it can compromise the safety of traffic users; (c) state revenue is reduced when roads are used for purposes other than transport (tax calculation in Poland is based on the land use and the size of its area; if a right-of-way is occupied by buildings, home gardens, lawns or arable land, the person using the land does not pay taxes for such areas because public roads are exempt from tax [88,89]); (d) lack of LU-LC consistency for a right-of-way can block the space development because issuing a permit for an investment project requires that an appropriate distance should be left between the right-of-way boundary and newly erected structures [70,90].

Managing road infrastructure is associated with a broad range of actions which may lead to numerous conflicts in some situations, which can be alleviated when full spatial information is available. The proposed algorithms take into account the most frequently occurring methods of improper use of the right-of-way. These include: A building corner, a home garden, a plot fence, agricultural use, an advertising structure, technical infrastructure, and a secondary road (a road area administered by an authority other than the General Directorate for National Roads and Motorways). These algorithms enable the successful synchronisation of the land use with the land cover; they are consistent with the applicable regulations, judgments of courts and the principles of good practice.

\section{Conclusions}

Monitoring of LU-LC changes has become an important issue in studying not only global environmental changes in recent years, but also affect local activities, in particular road administrators.

Each road administrator should possess information on the spatial range of objects that he administers. Public road data in cadastral documents do not always reflect the situation on the ground. This manuscript innovatively combines the LU-LC incompatibilities detecting method using Corine Land Cover data with the synchronisation algorithms LU-LC taking into account different land cover of the right-of-way. The LU-LC incompatibilities concerned primarily for: Objects erected before 1985 (the synchronisation algorithm in Figure 9); occupation of a right-of-way by a fence or a gate (synchronisation algorithm in Figure 11); technical infrastructure devices (synchronisation algorithm in Figure 12); advertisements (synchronisation algorithm in Figure 13); crop (synchronisation algorithm in Figure 15); a home garden, an orchard, an afforested area/forest (synchronisation algorithm in Figure 17); land owned by individuals/legal entities occupied by public roads and associated devices 
(synchronisation algorithm in Figure 18) and land taken over by local government units (State Treasury/commune/county/voivodship) other than the road administrator (synchronisation algorithm in Figure 19). The study showed that it is difficult to solve the LU-LC discrepancy problem, both from the administrative and legal, and from the social perspective (see algorithm Figure 18 showing a conflict with the landowner). Consequences of a lack of LU-LC synchronisation affect not only the national budget (as revenues from taxes or fees for occupying a right-of-way) as well as the EU budget (areas qualified for area-related fees).

This study had some weak points. The algorithms of achieving the LU-LC consistency were applied to the most common cases in an area. Probably, not all examples of solutions were included, but in the opinion of the manuscript authors, other cases can be fitted into the proposed solutions. Another limitation is the number of analysed cases of LU-LC discrepancies. Quantitative studies are more like case studies than a diagnosis of the LU-LC condition on national roads in Poland. The proposed synchronisation algorithms are universal and can be applied in an area with coherent laws. These limitations and weak points will be elaborated on in further studies.

Supplementary Materials: Supplementary 1. Data used for modelling http://www.mdpi.com/2072-4292/11/24/ 3053/s1.

Author Contributions: Conceptualization, K.K.B.; methodology, K.K.B., A.D.; software, K.K.B.; validation, K.K.B., A.D.; formal analysis, K.K.B., A.D.; investigation, K.K.B.; resources, K.K.B.; data curation, K.K.B.; writing-original draft preparation, K.K.B.; writing-review and editing, K.K.B.; visualization, K.K.B.; supervision, K.K.B.; project administration, K.K.B.; funding acquisition, K.K.B.

Funding: This research received no external funding.

Acknowledgments: The authors wish to offer special thanks to the General Directorate for National Roads and Highways, Olsztyn Branch, for sharing the materials used for experiments and to Roman Grzelka for inspiring comments which helped to prepare this manuscript.

Conflicts of Interest: The authors declare no conflicts of interest.

\section{Abbreviations}

The following abbreviations are used in this manuscript:

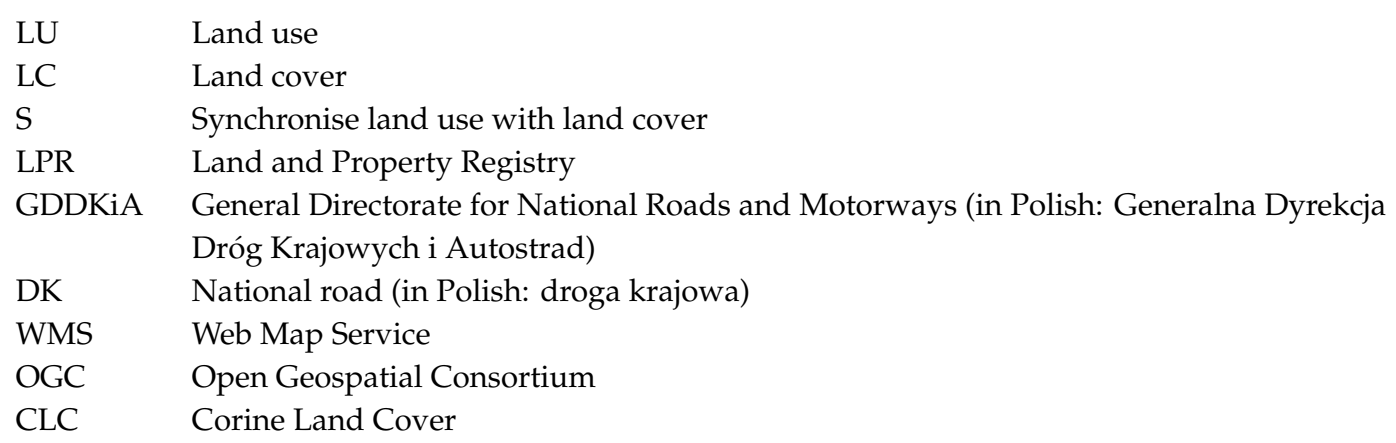

\section{References}

1. Noga, K.; Balawejder, M.; Matkowska, K. Dimensions of the destruction of road network providing access to cadastral parcels resulting from the motorway construction. Geomat. Environ. Eng. 2017, 11, 65-81. [CrossRef]

2. Kos, B. Directions for Improving the Efficiency of Road Network Management in Poland. Stud. Ekonom. 2013, 136, 149-164.

3. Krajczyńska, E. Badanie: W Europie Wschodniej Dobra Wspólne to Wciąż Dobra Niczyje. Nauka w Polsce. Człowiek 12 April 2017. Ministerstwo Nauki i Szkolnictwa Wyższego. Available online: http://scienceinpoland. pap.pl/aktualnosc (accessed on 15 October 2019).

4. Fan, Y.; Yu, G.; He, Z.; Yu, H.; Bai, R.; Yang, L.; Wu, D. Entropies of the Chinese Land Use/Cover change from 1990 to 2010 at a County level. Entropy 2017, 19, 51. [CrossRef] 
5. Prus, B.; Gawroński, K.; Ulicka, K. Historical changes in land use in rural areas of southern Poland-case study. Studia 2018, 50, 9-24.

6. Foley, J.A.; DeFries, R.; Asner, G.P.; Barford, C.; Bonan, G.; Carpenter, S.R.; Chapin, F.S.; Coe, M.T.; Daily, G.C.; Gibbs, H.K.; et al. Global consequences of land use. Science 2005, 309, 570-574. [CrossRef]

7. Verburg, P.H.; van de Steeg, J.; Veldkamp, A.; Willemen, L. From land cover change to land function dynamics: A major challenge to improve land characterization. J. Environ. Manag. 2009, 90, 1327-1335. [CrossRef]

8. Falcucci, A.; Maiorano, L.; Boitani, L. Changes in land-use/land-cover patterns in Italy and their implications for biodiversity conservation. Landsc. Ecol. 2007, 22, 617-631. [CrossRef]

9. Grešlová, P.; Štych, P.; Salata, T.; Hernik, J.; Knížkovád, I.; Bičíka, I.; Jelečeka, L.; Prus, B.; Noszczyk, T. Agroecosystem energy metabolism in Czechia and Poland in the two decades after the fall of communism: From a centrally planned system to market oriented mode of production. Land Use Policy 2019, 82, 807-820. [CrossRef]

10. Sallay, A.; Jombach, S. Changing landscape values in Hungary. Probl. Ekol. Kraj. 2011, 30, $225-232$.

11. Bogoliubova, A.; Tymków, P. Land cover changes and dynamics of the Yuntolovsky Reserve. Electr. J. Pol. Agric. Univ. 2014, 17, 3. Available online: http://www.ejpau.media.pl/volume17/issue3/art-03.html (accessed on 20 March 2019).

12. Kazak, J. The use of a decision support system for sustainable urbanization and thermal comfort in adaptation to climate change actions—-the case of the Wrocław Larger Urban Zone (Poland). Sustainability 2018, 10, 1083. [CrossRef]

13. Lambin, E.F.; Turner, B.L.; Geist, H.J.; Agbola, S.B.; Angelsen, A.; Bruce, J.W.; Coomes, O.T.; Dirzo, R.; Fischer, G.; Folke, C.; et al. The causes of land-use and land-cover change: Moving beyond the myths. Glob. Environ. Chang. 2001, 11, 261-269. [CrossRef]

14. Lambin, E.F.; Geist, H.J.; Lepers, E. Dynamics of land-use and land-cover change in tropical regions. Ann. Rev. Environ. Res. 2003, 28, 205-241. [CrossRef]

15. Matson, P.A.; Parton, W.J.; Power, A.G.; Swift, M.J. Agricultural intensification and ecosystem properties. Science 1997, 277, 504-509. [CrossRef]

16. Karimi, M.; Mesgari, M.S.; Sharifi, M.A.; Pilehforooshha, P. Developing a methodology for modelling land use change in space and time. J. Spat. Sci. 2017, 62, 261-280. [CrossRef]

17. Noszczyk, T. Is the obligation to monitor land use change in Poland complied with? Form. Circumiectus 2018, 17, 11-19. [CrossRef]

18. Kim, C. Land use classification and land use change analysis using satellite images in Lombok Island, Indonesia. For. Sci. Technol. 2016, 12, 183-191. [CrossRef]

19. Bagnicki, J.; Mika, M. Analiza niezgodności danych opisowych działki (nieruchomości) na przykładzie wybranego obrębu ewidencyjnego. Infrastrukt. I Ekol. Teren. Wiej. 2013, 2, 99-110. (In Polish)

20. Kocur-Bera, K. Data compatibility between the Land and Building Cadaster (LBC) and the Land Parcel Identification System (LPIS) in the context of area-based payments: A case study in the Polish Region of Warmia and Mazury. Land Use Policy 2019, 80, 370-379. [CrossRef]

21. Meha, M.; Khem, K.; Cake, M.; Sinani, Q.; Ahmetaj, K. Systematic Cadastral Registration Using UAV Technology; Kosovo Cadastral Agency: Pristina, Kosovo, 2016.

22. Salata, T.; Prus, B. Geodata modelling applied to the planning and land use of rural areas in conjunction with the Polish spatial information infrastructure. In Land Ownership and Land Use Development. The Integration of Past, Present and Future in Spatial Planning and Land Management Policies; Hepperle, E., Dixon-Gough, R., Mansberger, R., Paulson, J., Hernik, J., Kalbro, T., Eds.; vdf Hochschulverlag AG an der ETH Zürich; European Academy of Land Use Development: Zurich, Switzerland, 2017; pp. 195-208.

23. Harrie, L.; Hellström, A.K. A prototype system for propagating updates between cartographic data sets. Cartogr. J. 1999, 36, 133-140. [CrossRef]

24. Badard, T.; Lemarié, C. Propagating Updates between Geographic Databases with Different Scales; Chapter 10 of Innovations in GIS VII: GeoComputation; Atkinson, P., Martin, D., Eds.; Taylor and Francis: London, UK, 1999; pp. 135-146.

25. Willrich, F. Quality control and updating of road data by GIS-driven road extraction from imagery. In Proceedings of the Symposium on Geospatial Theory, Processing and Applications, Ottawa, Canada, 8-12 July 2002; pp. 1-7. Available online: https://pdfs.semanticscholar.org/e07e/8050863dc7b8bc791b8a7547437834ccdb42.pdf?_ga=2. 70702480.1090911911.1559565628-257693347.1554364820 (accessed on 15 October 2019). 
26. Hu, Y.G.; Chen, J.; Li, Z.L.; Zhao, R.L. Road data updating using tools of matching and map generalization. Int. Arch. Photogramm. Remote Sens. Spat. Inf. Sci. XXXVII Part B4 2008, 291-296. Available online: https://www.isprs.org/proceedings/XXXVII/congress/4_pdf/52.pdf (accessed on 15 October 2019).

27. Zampieri, A.; Charpiat, G.; Tarabalka, Y. Coarse to fine non-rigid registration: A chain of scale-specific neural networks for multimodal image alignment with application to remote sensing. arXiv. 2018. Available online: https://hal.inria.fr/hal.01718263/document (accessed on 10 October 2019).

28. Girard, N.; Charpiat, G.; Tarabalka, Y. Aligning and Updating Cadaster Maps with Aerial Images by Multi-task, Multi-resolution Deep Learning. In Computer Vision-ACCV Lecture Notes in Computer Science; Jawahar, C., Li, H., Mori, G., Schindler, K., Eds.; Springer: Cham, Switzerland, 2018; Volume 11365. [CrossRef]

29. Ghimbăşan, A.C.; Vorovencii, I.; Căţeanu, M. Using images acquired from a rural area with unmanned aerial vehicle in order to achieve the land and constructions cadaster. In Proceedings of the Biennial International Symposium Forest and Sustainable Development, Brașov, Romania, 25-27 October 2018.

30. Klapa, P.; Mitka, B. Application of terrestrial laser scanning to the development and updating of the base map. Geod. Cartogr. 2017, 66, 59-72. [CrossRef]

31. Noszczyk, T.; Hernik, J. Modernization of the land and property register. Acta Sci. Pol. Form. Circumiectus 2016, 15, 3-17. [CrossRef]

32. Noszczyk, T.; Hernik, J. Understanding the cadastre in rural areas in Poland after the socio-political transformation. J. Spat. Sci. 2017, 64, 73-95. [CrossRef]

33. Kocur-Bera, K.; Stachelek, M. Geo-Analysis of Compatibility Determinants for Data in the Land and Property Register (LPR). Geosciences 2019, 9, 303. [CrossRef]

34. Hanus, P.; Pęska-Siwik, A.; Szewczyk, R. Spatial analysis of the accuracy of the cadastral parcel boundaries. Comput. Electron. Agric. 2018, 144, 9-15. [CrossRef]

35. Carrilho, J.; Marques, M.R.; Balas, M.; Macate, Z.; Lemmen, C.H. Addressing Fuzzy Boundaries in Community Delimitations for Systematic Cadastre in Mozambique. In Proceedings of the World Bank Conference on Land and Poverty, The World Bank, Washington, DC, USA, 25-29 March 2019.

36. Ch, R.; Shapiro, J.; Steele, A.; Vargas, J. Endogenous Taxation in Ongoing Internal Conflict: The Case of Colombia. Am. Political Sci. Rev. 2018, 112, 996-1015. [CrossRef]

37. Acta of 2 March 1985 on Public Roads (Journal of Laws 14, Item 60). Available online: http://www.isap.gov.pl (accessed on 16 October 2019).

38. Kotowski, W.; Kurzępa, B.; Kot, Ł. Drogi Publiczne. Budowa, Utrzymanie, Finansowanie; Wydawnictwo C.H. Beck Warszawa: Warsaw, Poland, 2014; p. 230. ISBN 978-83-255-6705-7.

39. Cybulski, B. Podstawowe Definicje z Kodeksu Drogowego. Available online: https://slideplayer.pl/slide/ 7605127/ (accessed on 12 August 2019).

40. Bennett, R.; Rajabifard, A.; Kalantari, M.; Wallace, J.; Williamson, I. Cadastral Futures: Building a New Vision for the Nature and Role of Cadastres. Article of the Month-June 2011; International Federation of Surveyors. Available online: https://www.fig.net/resources/monthly_articles/2011/june_2011/june_2011_ bennett_rajabifard_et_al.pdf (accessed on 10 October 2019).

41. Mika, M. An analysis of possibilities for the establishment of a multipurpose and multidimensional cadastre in Poland. Land Use Policy 2018, 77, 446-453. [CrossRef]

42. Geodetic and Cartographic Law of 17 May 1989 (Journal of Laws 30, item 163). Available online: http: //www.isap.gov.pl (accessed on 14 October 2019).

43. Noszczyk, T.; Hernik, J. The necessity to keep land and property registers in an active manner. Instrastruktura I Ekol. Teren. Wiej. 2017, 2, 229-241. [CrossRef]

44. Facenoben, D. Kryteria oceny jakości danych i informacji, gromadzonych i udostepnianych $\mathrm{z}$ katastru nieruchomości. Prz. Geod. 2011, 83, 11-17.

45. Hopfer, A.; Cegielski, S.; Pietrzak, L. Reformy katastru nieruchomości w Polsce w skali lokalnej i globalnej, Сучасні досягнення геодезичної науки та виробництва, Збірник наукових праць Західного геодезичного товариства УТГК. КАДАСТР 2012, 2, 12-25. Available online: http://ena.lp.edu.ua:8080/bitstream/ntb/ 16089/1/28_Hopfer_121_125_geodesy_24.pdf (accessed on 10 October 2019).

46. Regulation of the Minister of Regional Development and Construction on 29 March 2001 on the Registration of Land and Buildings. Available online: http://www.isap.gov.pl (accessed on 3 March 2019).

47. Act of 20 July 2017 Water Law (Journal of Laws, Item 1566). Available online: http://www.isap.gov.pl (accessed on 14 July 2019). 
48. Act of 21 August 1997 on Real Estate Management (Journal of Laws 115, Item 741). Available online: http://www.isap.gov.pl (accessed on 4 March 2019).

49. Amoureus, L.; Bomers, M.P.; Fuser, R.; Tosatto, M. Integration of LiDAR and Terrestrial Mobile Mapping Technology for the Creation of a Comprehensive Road Cadastre. In Proceedings of the 5th International Symposium on Mobile Mapping Technology, Padua, Italy, 29-31 May 2007, ISPRS Archives, XXXVI-5/C55.

50. Kołodziejski, J. Ekologiczne zasady gospodarowania przestrzenią. In W: Ekologiczne Podstawy Gospodarowania Środowiskiem Przyrodniczym. Wizje-Problemy-Trudności; Red, S., Mazur, W.Y.D., Eds.; SGGW-AR: Warszawa, Poland, 1991; pp. 244-254.

51. Adamus-Matuszyńska, A. Wspótczesne Teorie Konfliktu Społecznego; Wyd. Akademii Ekonomicznej im. Karola Adamieckiego w Katowicach: Katowice, Poland, 1998; p. 115.

52. Hackiewicz, M. Społeczne i prawne aspekty konfliktów na tle zagospodarowania przestrzennego na przykładzie budowy obwodnicy Milanówka i Grodziska mazowieckiego. Maz. Studia Reg. 2011, 6, 123-148.

53. Central Statistical Office. 2013. Available online: www.stat.gov.pl (accessed on 10 August 2019).

54. Road Transport in Poland in the 2013. Statistical Information and Elaborations. Available online: www.stat. gov.pl (accessed on 10 August 2019).

55. Google Maps. Available online: www.google.pl (accessed on 10 August 2019).

56. GDDKiA (General Direcorate for National Roads and Motorways). Klasy dróg Krajowych w Województwie Warmińsko-Mazurskim (Classes of National Roads in Warmińsko-Mazurskie Voivodeship). 2019. Available online: https://www.gddkia.gov.pl/pl/a/126/klasy (accessed on 10 August 2019).

57. Noszczyk, T.; Rutkowska, A.; Hernik, J. Determining changes in land use Structure in Małopolska using statistical methods. Pol. J. Environ. Stud. 2017, 26, 211-220. [CrossRef]

58. Rosienkiewicz, M. Efficiency comparison of Akaike and Hellwig methods in constructing regression model. Wiadomości Stat. 2012, 10, 27-43. Available online: www.stst.gov.pl (accessed on 20 November 2019).

59. Malpezzi, S.; Gibb, K.; O'Sullivan, A. Hedonic Pricing Models: A Selective and Applied Review. J. Hous. Econ. 2003, 67-89. [CrossRef]

60. Baranzini, A.; Ramirez, J.; Schaerer, C.; Thalmann, P. Hedonic Methods in Housing Markets: Pricing Environmental Amenities and Segregation; Springer-Verlag: New York, NY, USA, 2008. [CrossRef]

61. Khalid, H. Spatial heterogeneity and spatial bias analyses in hedonic price models: Some practical considerations. Bull. Geogr. Socio Econ. Ser. 2015, 28, 113-129. [CrossRef]

62. de Haan, J.; Diewert, E. Handbook on Residential Property Price Indices. Eurostat, Methodologies and Working papers: Eurostat, Luxembourg, 2013; pp. 49-64. [CrossRef]

63. Wen, H.; Jia, S.; Guo, X. Hedonic Price Analysis of Urban Housing: An Empirical Research on Hangzhou, China. J. Zhejiang Univ. 2005, 6, 907-914. [CrossRef]

64. Sopranzetti, B.J. Hedonic Regression Analysis in Real Estate Markets: A Primer. In Handbook of Quantitative Finance and Risk Management. Theory, Methodology and Applications; Springer: Boston, MA, USA, 2010; pp. 1201-1207. [CrossRef]

65. Widłak, M. Dostosowanie indeksów cenowych do zmian jakości. Metoda wyznaczania hedonicznych indeksów cen i możliwości ich zastosowania dla rynku mieszkaniowego. Mater. I Studia 2010, 247, 1-28. Available online: http://www.nbp.pl (accessed on 1 October 2019).

66. Cebula, R.J. The Hedonic Pricing Model Applied to the Housing Market of the City of Savannah and Its Savannah Historic Landmark District. Rev. Reg. Stud. 2009, 39, 9-22. Available online: https://www.researchgate.net/publication/254447595_The_Hedonic_Pricing_Model_Applied_to_the_Housing Market_of_the_City_of_Savannah_and_Its_Savannah_Historic_Landmark_District (accessed on 10 May 2019).

67. Directive 2007/2/ EC of the European Parliament and of the Council of 14 March 2007 Establishing an Infrastructure for Spatial Information in the European Community (INSPIRE). Available online: http: //data.europa.eu/eli/dir/2007/2/oj (accessed on 14 June 2019).

68. GDDKiA. Zestawienie wyników aktualizacji geodezyjnej pasa drogowego w 2019. Generalna Dyrekcja dróg Krajowych i Autostrad, oddział w Olsztynie (accessed in GDDKiA, Olsztyn). Available online: https://www.gddkia.gov.pl/pl/401/gddkia-olsztyn.

69. Geoportal, Interactive Map. Available online: www.mapy.geoportal.gov.pl (accessed on 4 July 2019).

70. Voivodeship Administrative Court in Lublin, III SA/Lu 53/12 z 29 Marca 2012 r. Available online: http: //orzeczenia.nsa.gov.pl (accessed on 10 July 2019). 
71. Act of 14 July 1960 Code of Administrative Procedure, (Journal of Laws 30, Item 168). Available online: http://www.isap.gov.pl (accessed on 6 September 2019).

72. Supreme Administrative Court of 13 September 2005, Sygn. Akt OSK 782/04. Available online: http: //www.orzeczenia-nsa.pl (accessed on 20 July 2019).

73. Vodministrative Court in Poznań, III SA/Po 280/18. 2018. Available online: http://orzeczenia.nsa.gov.pl (accessed on 10 July 2019).

74. Glicz, M.; Jamroz, K.; Mackun, T. Aktualny stan prawny w zakresie reklam widzianych z drogi i rekomendacje do zmian. Transp. Miej. Reg. 2013, 12, 1-15.

75. Act of 12 January 1991 on Local Taxes and Fees (Journal of Laws 9, Item 31). Available online: http: //www.isap.gov.pl (accessed on 6 September 2019).

76. Act of 24 April 2015 on the Amendment of Some Acts in Connection with the Strengthening of Landscape Protection Tools (Journal of Laws, Item 774). Available online: http://www.isap.gov.pl (accessed on 6 August 2019).

77. Act of 16 April 2004 on Nature Protection (Journal of Laws, Item 627). Available online: http://www.isap.gov.pl (accessed on 6 August 2019).

78. Act of 13 October 1998 Introducing the Law Reforming Public Administration (Journal of Laws 136, Item 872). Available online: http://www.isap.gov.pl (accessed on 6 August 2019).

79. Act of 10 May 1990 Introducing the Act on Local Government and the Act on Local Government Employees (Journal of Laws 32, Item 191). Available online: http://www.isap.gov.pl (accessed on 16 August 2019).

80. SO w Łomży, I Ca 439/17 z 08 Febrary 2018. Available online: http://orzeczenia.lomza.so.gov.pl/ (accessed on 5 August 2019).

81. Forman, R.T.T.; Sperling, D.; Bissonette, J.; Clevenger, A.P.; Cutshall, C.; Dale, V.; Fahrig, L.; France, R.; Goldman, C.; Heanue, K.; et al. Road Ecology: Science and Solutions; Island Press: Washington, DC, USA, 2003; p. 504, ISBN 9781559639330.

82. Kocur-Bera, K.; Dudzinska, M. Roadside vegetation-the impact on safety. In Proceedings of the Conference Engineering For Rural Development, Jelgava, Latvia, 20-22 May 2015; Available online: http://www.tf.llu.lv/ conference/proceedings2015/Papers/097_ (accessed on 10 August 2019).

83. Sadowski, A.; Poczta, W.; Beba, P.; Szuba-Barańska, E. Productivity Diversification by Farm Category in the European Union. Village Agric. 2016, 170, 127-138. [CrossRef]

84. Pawlak, J. Role of Mechanization in the Development of Agriculture. Roczniki Nauk Rolniczych, G-97. 2010, pp. 165-175. Available online: http://www.wne.sggw.pl/czasopisma/pdf/RNR_2010_T97_z2.pdf (accessed on 13 September 2019).

85. Każmierczyk, A.; Michałowska, K. The evolution of ownership during the economic transformation of the turn of XX th and XXI st century. Res. Pap. Wroc. Univ. Econ. 2014, 362, 182-195.

86. Kocur-Bera, K. Determinants of agricultural land price in Poland-A case study covering a part of the Euroregion Baltic. Cah. Agric. 2016, 25, 25004. [CrossRef]

87. Bórawski, P.; Bełdycka-Bórawska, A.; Szymańska, E.J.; Jankowski, K.J.; Dunn, J.W. Price volatility of agricultural land in Poland in the context of the European Union. Land Use Policy 2019, 82, 486-496. [CrossRef]

88. Act of 7 July 1994 on Building Low (Journal of Laws, Item 1186). Available online: http://www.isap.gov.pl (accessed on 6 October 2019).

89. Modelska, K. Wybrane problemy aktualizacji użytków gruntowych na przykładzie inwestycji drogowych. Infrastrukt. Ekol. Obsz. Wiej. 2013, 2/III, 59-70.

90. Regulation of the Minister of Infrastructure and Development on 12 April 2002 on the on the Technical Conditions to be Met by Buildings and Their Location (Journal of Lows, Item 1422). Available online: http://www.isap.gov.pl (accessed on 3 March 2019).

(C) 2019 by the authors. Licensee MDPI, Basel, Switzerland. This article is an open access article distributed under the terms and conditions of the Creative Commons Attribution (CC BY) license (http://creativecommons.org/licenses/by/4.0/). 